\title{
Microbial driven iron deduction affects arsenic transformation and transportation in soil-rice system
}

by Xue, S., Jiang, X., Wu, C., Hartley, W., Qian, Z., Luo, $\mathrm{X}$. and $\mathrm{Li}, \mathrm{W}$.

Copyright, publisher and additional Information: This is the author accepted manuscript. The final published version (version of record) is available online via Elsevier.

This version is made available under the CC-BY-ND-NC licence:

https://creativecommons.org/licenses/by-nc-nd/4.0/legalcode

Please refer to any applicable terms of use of the publisher

DOI: https://doi.org/10.1016/j.envpol.2020.114010 
1 Microbial driven iron reduction affects arsenic transformation and transportation in

2 soil-rice system.

3

4 Shengguo Xue, Xingxing Jiang, Chuan Wu, William Hartley, Ziyan Qian, Xinghua

5 Luo, Waichin Li.

$6 \quad{ }^{*}$ Corresponding author:

$7 \quad$ Tel.:+86-15273172436, E-mail address: wuchuan@ csu.edu.cn (Chuan Wu)

8

9

10

11

12

13

14

15

16

17

18 
19

20 Abstract

21

22

23

24

25

26

27

28

29

30

31

32

33 


\section{INTRODUCTION}

Arsenic (As) is the most widespread toxic element in nature. The average concentration in the Earth's crust and soil is 2.1 and $5 \mathrm{mg} / \mathrm{kg}$ respectively, ranking 20th in the crustal abundance of elements (Frost et al., 2003; Zhao et al., 2010). Agricultural and industrial production, including mining, smelting, fertilizer and pesticide applications, wood preservation and feed additions are important sources of environmental As contamination (Bahar et al., 2012; Charlet and Polya, 2006). Anthropogenic emissions of As in global soils is between $2.84 \times 10^{5}$ $-9.4 \times 10^{5} \mathrm{t}$ (Zhu et al., 2014). Soil As pollution not only causes secondary pollution of surface waters and groundwater, but for paddy soils, it also reduces crop yield and quality, whilst adversely affecting human health through food chain transfer (Khan et al., 2010). In 2014, the Ministry of Environmental Protection and the Ministry of Land and Resources surveyed China's soil pollution status, revealing that $19.4 \%$ of farmland soils were contaminated with As (Zhao et al., 2015). Arsenic contamination has become a global environmental problem, especially in Southeast Asia, where groundwater and soil As contamination have attracted the attention of researchers from around the world (Seyfferth et al., 2014). Rice is the most important food crop in China and the staple food of half of the world's population (Khush, 2013).

2 Studies have shown that per capita, for Chinese residents, As intake is about $42 \mu \mathrm{g} / \mathrm{d}$,

53 whilst As in rice accounts for $60 \%$ of the total daily intake (Zhu et al., 2008). Arsenic 4 contamination seriously threatens the health of populations with a rice-based diet, and 
55

this has become the main exposure route besides contaminated drinking water (Singh et al., 2015).

Microbial conversion of As is an important part of its geochemical cycle (Huang et al., 2011). Sforna et al. (2014) revealed that the microbial metabolism of As began 2.7 billion years ago, including redox and methylation of As in microbial cells (Sforna et al., 2014). Microbial regulation of As determines its morphological transformation and hence its environmental fate and bioavailability in paddy soils (Zhang et al., 2015). Arsenic oxidizing bacteria such as Paracoccus sp. SY and Alkalilimnicola ehrlichii, from arsenic-contaminated soils and alkaline hypersaline soda lakes, for example, can oxidize trivalent arsenic to pentavalent arsenic, and so reduce its mobility and bioavailability (Yamamura and Amachi, 2014; Zhang et al., 2015). Arsenate-resistant microorganisms and certain dissimilatory arsenate-reducing prokaryotes such as Chrysiogenes arsenatis and Bacillus selenatarsenatis, can reduce $\mathrm{As}(\mathrm{V})$ to $\mathrm{As}(\mathrm{III})$ by intracytoplasmic reductase (ArsC) and anaerobic respiration. Arsenate adsorbed on the surface of iron (hydrogen) oxides acts as a terminal electron acceptor, thus leading to the activation of As in paddy soils, consequently promoting absorption and accumulation of As in rice (Yamamura et al., 2005; Zhang et al., 2015). Arsenic methylation is catalyzed by As(III) adenosylmethionine methyltransferase (ArsM), in which the methyl group is transferred from adenosylmethionine to As(III), and is subsequently methylated from $\mathrm{As}(\mathrm{III})$ to $\mathrm{As}\left(\mathrm{CH}_{3}\right)_{\mathrm{n}}$ (Ye et al., 2012). Since the toxicity of monomethylarsine is much less than inorganic arsenic, promoting the methylation of As in soils is an effective way to alleviate arsenic pollution in 
farmlands. Zhang et al. (2015) found that As transformation genes in paddy soils were widely distributed, highly diverse and abundant, and mainly from rice rhizosphere bacteria, such as Proteobacteria, Gemmatimonadales, and Funicutes (Zhang et al., 2015). Soil physicochemical properties (pH, EC, total carbon, nitrogen, As and iron, $\mathrm{C} / \mathrm{N}$ ratio, sulfate and nitrate ions) and rice rhizosphere environments (mucigels, polysaccharides, amino acids and organics secreted by the roots) all affect As metabolism by microorganisms, which can increase microbial abundance and change the microbial community structure (Bais et al., 2006).

Soil minerals and organic matter greatly affect As mobility, bioavailability, and toxicity in soils (Kim et al., 2015). Iron (hydrogen) oxide is a very common mineral in soil, including ferrohydrite, hematite, goethite, fibrite, magnetite etc (Doušová et al., 2011). Due to its large specific surface area, positive surface charge and sufficient adsorption sites, it has a strong adsorption capacity for anions such as arsenate (Ackermann et al., 2010). Through microbial action, the redox process of iron leads to adsorption, release and coprecipitation processes, and may cause transformation of As species (Shi et al., 2018). Identifying the mechanism of Fe(II, III) redox system on As speciation is an effective way to control As pollution in paddy fields, whilst microbial-mediated processes of dissimilatory iron reduction, play an important role in the As biogeochemical cycle (Borch et al., 2010). The transportation and speciation of heavy metals such as chromium, arsenic and selenium in anaerobic circumstances are closely related to iron reduction processes (Yan et al., 2004). Stroud et al. (2011) reported that the reduction of $\mathrm{Fe}(\mathrm{III})$ caused the release and reduction of $\mathrm{As}(\mathrm{V})$ 
adsorbed on iron (hydrogen) oxide (Stroud et al., 2011). However, recent studies have

100 shown that dissimilatory iron reduction processes may promote the adsorption of As,

101 because of formed secondary iron minerals which promote As fixation, causing a

102 decrease in As mobility (Guo et al., 2013; Tufano and Fendorf, 2008). Furthermore,

103 generated As(III) may be more likely to adsorb on iron minerals than As(V) (Jiang et

104 al., 2013). Jiang et al. (2013) showed that under the action of iron-reducing bacteria

such as S. oneidensis $M R-1$ and Shewanella sp. $H N-41$, the concentration of As(V) in solution decreased because $\mathrm{As}(\mathrm{V})$ and $\mathrm{Fe}(\mathrm{II})$ produced in solution formed a ferrous arsenate coprecipitate (Jiang et al., 2013).

Radial oxygen loss (ROL) from rice roots, results in iron (hydrogen) oxide plaque formation, being mainly composed of ferrihydrite, goethite and fibrite, which can strongly adsorb As on root surfaces, consequently reducing As transportation to aboveground rice tissues ( $\mathrm{Wu}$ et al., 2016). Studies have revealed that the microaerobic status of rhizosphere soils has led to the relative abundance of As oxidizing bacteria being higher than that of As reducing bacteria. This has enhanced oxidation of As(III) and promoted an increase in As adsorption by the iron plaque (Jia et al., 2014). However, understanding how the rhizosphere process affects microbial activity and the subsequent effects on As migration, speciation, and rice As accumulation, requires further investigation.

Although there are studies regarding the effects of radial oxygen loss from roots on As accumulation in rice, as well as As biotransformation related genes in paddy soils, little research has been conducted on the effects of iron reduction genes on As 
121 biotransformation, and As transportation and speciation in soil-rice systems. The objectives of the present work were to 1) to study the effects of iron reduction genes on As biotransformation related genes' abundances in paddy soils; 2) to study the effects of iron reduction genes on rice rhizosphere physicochemical properties, As/Fe concentrations in soil pore water, as well as As transportation and speciation in

\section{different rice genotypes.}

\section{MATERIALS AND METHODS}

\section{Experimental setup}

The contaminated paddy soils for pot experiments were collected from a paddy filed (1-20 cm depth) around a mining area in Chenzhou City, Hunan Province. Mean soil As and Fe concentrations were $130.20 \mathrm{mg} / \mathrm{kg}^{-1}$ and $40.03 \mathrm{~g} / \mathrm{kg}^{-1}$ respectively; other selected basic soil properties are listed in Table S1. Four rice genotypes were selected for the investigation; two hybrid subspecies, Shenyou 9586 (SY-9586) and Fengyuanyou 299 (FYY-299) and two indica subspecies, Xiangwanxian 17 (XWX-17) and Xiangwanxian 12 (XWX-12). Seeds were surface sterilized by soaking in $30 \%$ $\mathrm{H}_{2} \mathrm{O}_{2}$, and subsequently transferred to a petri dish covered by moist filter paper for germination to seedlings $(\sim 2-3 \mathrm{~cm})$. Seedlings were then cultivated in a nutrient solution for 2 weeks prior to the pot investigation (Wu et al., 2017). Four uniform rice seedlings of each genotype (SY-9586, FYY-299, XWX-17 and XWX-12) were selected and transplanted into the central area (rhizosphere) of $1 \mathrm{~kg}$ contaminated paddy soil in polyethylene pots $(30 \mathrm{~cm}$ high, bottom diameter $24 \mathrm{~cm}$, top diameter 28 
$\mathrm{cm})$ and covered with a nylon mesh $(24 \mu \mathrm{m})$ bag (height of $15 \mathrm{~cm}$; diameter of $12 \mathrm{~cm}$ ). At the same time, the outside area of soil (bulk soil) was kept away from the rice roots, using $9 \mathrm{~kg}$ contaminated paddy soil (Jia et al., 2013a). Three rice seedlings were planted in each pot, and each genotype rice seedling was replicated four times, totaling 16 pots. Rice seedlings were grown under flooding conditions (water $2 \mathrm{~cm}$ higher than the soil surface) to simulate the actual paddy field environment. Pots were placed randomly in a greenhouse $\left(25^{\circ} \mathrm{C}\right.$ during the day and $20{ }^{\circ} \mathrm{C}$ at night, with $70 \%$ relative humidity) and natural light was supplemented with sodium light (1200 Lux), providing a photoperiod of $12 \mathrm{~h}$ light/12 h dark. Plants were cultured until harvest. The rhizosphere and bulk soil solutions of the four rice cultivars were sampled every 15 days as follows: tillering stage (15d), jointing stage (30d), heading stage (45d), early stage of filling (60d), mid-filling stage (75d), late stage of filling (90d) and maturity stage (105d)) using Rhizon Soil Moisture Samplers (Rhizosphere, Netherlands). Soil solutions were analyzed for $\mathrm{pH}$, electrical conductivity (EC), total As, and As speciation (As(III), As(V), DMA, MMA) and iron (Fe) content. At harvesting, root, straw, husk, and grain were separated, subsequently dried and ground for determination of Fe (as iron plaque), total As concentrations and As speciation.

\section{Chemical analysis of soil pore water and iron plaque}

The $\mathrm{pH}$ and redox potential (Eh) of soil pore waters were determined by a $\mathrm{pH}$ probe and meter (PHS-3C, Shanghai Precision Instrument Co., P.R. China). EC was measured by a conductivity meter. Iron and As contents were determined by atomic 
absorption spectrometer (AAS) and atomic fluorescence spectrometer (AFS)

respectively. As speciation was determined by high-performance liquid

167 chromatography-hydride generation atomic fluorescence spectrometry

168 (HLCP-HG-AFS) (Wu et al., 2016).

169 Iron and As concentrations of rhizosphere iron plaque were determined by DCB

170 (dithionite-citrate-bicarbonate solution) extraction (Wu et al., 2016). Iron and As

171 concentrations of the extraction were determined by AAS (AAS, TAS-990, Beijing

172 Puxi Instruments Co., P.R. China) and HG-AFS (HG-AFS, AFS-8230, Beijing Jitian

173 Instruments Co., P.R. China) respectively.

175 Plant analysis

176 Harvested mature rice plants were divided into four parts: root, straw, husk and 177 grain. Material was washed with tap water and then thoroughly rinsed with deionized 178 water. Rice samples were then divided into two parts, half was used to extract $\mathrm{Fe}$ 179 plaque, and the other half was placed in a vacuum freeze-drying oven for desiccation.

180 Following desiccation, the material was ground under liquid nitrogen conditions, and 181 arsenic contents and speciation of each part of the rice samples were determined. For 182 determination of total As in rice, $0.5 \mathrm{~g}$ of ground sample was digested with $1.0 \mathrm{ml}$ of 183 perchloric acid $\left(\mathrm{HClO}_{4}\right)$ and $4 \mathrm{ml}$ of nitric acid $\left(\mathrm{HNO}_{3}\right)\left(\mathrm{HNO}_{3}: \mathrm{HClO}_{4}=4: 1\right)$ at $110-130^{\circ} \mathrm{C}$ in a heating block until the a clear solution was obtained with a certified 185 reference plant material (GSV-2, GWB07603) for quality control purpoes. For 186 determination of different As species in rice, $0.5 \mathrm{~g}$ of ground sample was extracted 
using $25 \mathrm{ml}$ of $1 \%$ nitric acid $\left(\mathrm{HNO}_{3}\right)$ at $95^{\circ} \mathrm{C}$ for $1.5 \mathrm{~h}$, then extractions were centrifuged at $5000 \mathrm{r} / \mathrm{min}$ for $10 \mathrm{~min}$ and the supernatant filtered $(0.22 \mathrm{~mm})(\mathrm{Wu}$ et al., 2016). Arsenic speciation was determined by HLCP-HG-AFS (Wu et al., 2016).

\section{Soil DNA extraction}

Rhizosphere and non-rhizosphere soils were analyzed by quantitative PCR (qPCR) for arsenic functional genes and iron reduction genes for the four rice genotypes at 15 days (tillering stage), 30 days (jointing stage), 75 days (filling stage) and 105 days (maturity stage). Soil samples were used to extract total microbial DNA using QuantiFast ${ }^{\circledR}$ SYBR ${ }^{\circledR}$ Green PCR Kit (Qiagen, Germany) according to the manufacturer's instructions.

Quantitative real-time PCR analysis of arsenic functional genes and iron reduction genes

To amplify aioA, arsC , arsM and Geo gene abundance in each sample, the primers of qPCR AroAdeg2F/AroAdeg2R(Inskeep et al., 2007), amlt-42-f/amlt-376-r(Sun et al., 2004), arsMF1/arsMR2(Jia et al., 2013a) and Geo564F/Geo840R(Somenahally et al., 2011) were used in a LightCycler® 480 II Fluorescence quantitative PCR instrument (Roche, Swiss), respectively. Details of qPCR programs are presented in the Supporting Information. 
210 Correlations between soil $\mathrm{pH}, \mathrm{EC}$, As contents, DCB-extractable Fe/As contents in

211 iron plaque, plant total As contents, rice genotypes as well as gene copy number were 212 drawn with Origin 9.0. The relationship between gene abundance for aioA, arsC, 213 arsM and Geo and physicochemical characteristics of soil solution samples were 214 evaluated using redundancy analysis (RDA) in CANOCO 5. Significant differences 215 were determined using one-way analysis of variance (ANOVA), and $* \mathrm{P}<0.05$ was 216 used as a statistically significant difference.

\section{Arsenic/iron in soil solutions}

通过图 1 及表 $1 、 \mathrm{~S} 2$ 分析不同时期水稻土壤溶液 $\mathrm{pH} 、 \mathrm{EC} 、$ 铁砷浓度变化, 深入 挖掘根际、非根际及不同水稻品种与土壤溶液性质的关系。

Fig. 1 shows the $\mathrm{pH}, \mathrm{EC}$ and concentrations of total Fe, As and As(III) in 223 rhizosphere and non-rhizosphere soil solutions from the four rice genotypes (SY-9586, 224 FYY-299, XWX-17, and XWX-12) at their different growth stages. During the culture 225 period, the differences between $\mathrm{pH}$ and the rhizosphere and non-rhizosphere soil 226 solutions were not significant ranging from 7.41 to 8.80 , but in general the $\mathrm{pH}$ value 227 firstly increased and then decreased, achieving a maximum $\mathrm{pH}$ of 8.80 at the middle 228 of the rice filling stage. Electrical conductivity (EC) of soil solutions and 229 non-rhizosphere soil solutions revealed a significant upward trend at 0-60d, then 230 significantly decreased, and then subsequently increasing again after 90d, with a 
range between $116.3-820.0 \mathrm{~ms} / \mathrm{cm}$. Iron content in rhizosphere and non-rhizosphere soil solutions showed an increase, reaching a maximum at maturity stage, ranging between $0.90-72.1 \mathrm{mg} / \mathrm{L}$. Rhizosphere soil solutions were slightly lower than those of non-rhizosphere solutions. The trend of As concentration in soil solutions was similar to that of $\mathrm{Fe}$, showing an upward trend with a range of $73.54-453.00 \mu \mathrm{g} / \mathrm{L}$; As concentrations in rhizosphere soil solutions were slightly higher than those in non-rhizosphere solutions. Arsenite concentrations in rhizosphere solutions gradually increased before the filling stage, but then decreased slightly during the maturity stage, with a range between $98.5-453.0 \mu \mathrm{g} / \mathrm{L}$ (Fig. 1). Similar to total As and Fe, the concentrations of $\mathrm{As}(\mathrm{III})$ in rhizosphere soil solutions were higher than those in non-rhizosphere solutions. In addition, the concentrations of Fe, total As and As(III) in the rhizosphere soil solutions of hybrid rice genotypes were higher than those of indica rice genotypes after early filling stage.

Table 1 and Table S2 show the correlations of various physicochemical properties in rhizosphere and non-rhizosphere soil solutions respectively, which present similar trends. In rhizosphere solutions, correlations between $\mathrm{pH}$ and $\mathrm{Fe}(* \mathrm{P}<0.05) / \mathrm{As}(\mathrm{III})$ $(* * * \mathrm{P}<0.001)$ concentrations displayed a significant negative correlation, with correlation coefficients -0.223 and -0.503 , respectively. EC significantly affected the concentrations of $\mathrm{Fe}(* * * \mathrm{P}<0.001)$ and total As $(* * * \mathrm{P}<0.001)$, with correlation coefficients of -0.455 and 0.375 respectively. Concentrations of $\mathrm{Fe}$ in soil solutions were significantly positively correlated with total As $(* * * \mathrm{P}<0.001)$ and As(III) $(* * * \mathrm{P}$ $<0.001$ ), with correlation coefficients 0.473 and 0.673 respectively. Total As and 
$253 \mathrm{As}(\mathrm{III})$ concentrations revealed a significant positive correlation $(* * * \mathrm{P}<0.001$, 254 correlation coefficient=0.447). In non-rhizosphere soil solutions, there were 255 significant negative correlations between $\mathrm{pH}$ and $\mathrm{EC}(* \mathrm{P}<0.05) / \mathrm{Fe}(* * * \mathrm{P}<0.001) /$ $256 \mathrm{As}(\mathrm{III})(* * * \mathrm{P}<0.001)$, with correlation coefficients of $-0.271,-0.351$ and -0.582 , 257 respectively. EC significantly affected concentrations of $\mathrm{Fe}(* * * \mathrm{P}<0.001)$ and $\mathrm{As}(\mathrm{III})$ $258(* * * \mathrm{P}<0.001)$, with correlation coefficients -0.445 and 0.417 respectively. There 259 were significant positive correlations between Fe concentration and total As $(* \mathrm{P}<0.05)$ 260 / As (III) $(* * * \mathrm{P}<0.001)$ in soil solutions, with correlation coefficients 0.232 and 0.836 261 respectively. Meanwhile, total As and As(III) concentration also showed a significant 262 positive correlation $(* \mathrm{P}<0.05$, correlation coefficient $=0.244)$. 
根据表 3 分析水稻根表铁膜中铁、砷含量与水稻孔隙水性质的关系; 根据表 2

268 数据得出不同水稻品种不同部位砷积累形态的分布关系, 结合表 $2 、 3$ 得出环境 269 因素对水稻砷积累的影响。

Table S3 presents root, straw and grain biomass of the four rice genotypes (SY-9586, FYY-299, XWX-17 and XWX-12). Biomass of root, straw and grain were 43.1-65.1 g/pot, 61.5-119.8 g/pot and 8.2-15.5 g/pot respectively. The concentrations of Fe and As in iron plaque from different rice genotypes are presented in Table S4. The results reveal that Fe concentration in iron plaque of XWX-17 was significantly higher than the other genotypes, with As concentration also being the greatest. There were significant genotypic differences in $\mathrm{Fe}$ concentration in the iron plaque $(* \mathrm{P}$ $<0.05)$.

Arsenic species in roots, straws, husks, and grains from the four rice genotypes (SY-9586, FYY-299, XWX-17 and XWX-12) are presented in Table 2. Total As contents in roots, straws, husks, and grains of the four rice cultivars were calculated by adding the different As species together, being $259.50-283.40 \mathrm{mg} / \mathrm{kg}, 15.50$ $-22.80 \mathrm{mg} / \mathrm{kg}, 6.26-10.31 \mathrm{mg} / \mathrm{kg}$ and $5.01-7.47 \mathrm{mg} / \mathrm{kg}$ respectively (Table 2). Arsenic mainly existed in rice plants as inorganic As species (As(III) and As(V)), whilst organic As species (DMA and MMA) accounted for only a small proportion of total As. The contents of As(III) and total As accumulated in the straws, husks, and

286 grains of indica rice (XWX-17 and XWX-12) were lower than that of hybrid rice 287 (SY-9586 and FYY-299). In rice grains, As( V) and MMA were not detected, at the 
same time, there were significant genotypic differences between As(III) and DMA concentrations.

According to Table 3, pH, EC and the concentration of Fe, As and As(III) in the rhizosphere soil solutions had different effects on the formation of iron plaque on the root surface and the total As concentration in different parts of rice. There were significant positive correlations between $\mathrm{Fe}$ concentrations in rhizosphere soil solutions and total As concentrations in rice roots $(* \mathrm{P}<0.05)$, with a correlation coefficient of 0.588 . The concentration of As(III) in soil solution was significantly positively correlated with $\mathrm{Fe}$ and As concentration in iron plaque, with correlation coefficients of 0.708 and 0.602 respectively. This indicates that the concentration of As(III) in rhizosphere soil solutions significantly increased the Fe/As contents in iron plaque, promoting the formation of iron plaque on root surfaces and the subsequent sequestration of arsenic.

\section{Arsenic functional transformation genes and iron reduction gene abundance on} rice rhizosphere and non-rhizosphere soil

\section{根据图 2 分析不同水稻品种根际和非根际在生长时期内土壤功能基因拷贝数的} 变化关系, 结合图 3 明确土壤溶液理化性质对土壤功能基因丰度的影响。

According to Fig. 2 (A) and (B), at the tillering stage, copy numbers of the aioA gene in non-rhizosphere and rhizosphere soils were $1.03 \times 10^{11} \sim 7.12 \times 10^{11}$ and $0.96 \times 10^{11} \sim 9.05 \times 10^{11} \mathrm{mg}^{-1}$ dry soil respectively. For the whole growth period of rice, except for XWX-12, the copy number of aioA in non-rhizosphere soils from the other 
310 three rice genotypes firstly increased but then decreased, reaching a maximum at the

311 jointing stage. There were no significant genotypic differences during the whole

312 growth period. The copy number of aioA gene in rhizosphere soil firstly increased at

313 jointing stage, then decreased during the filling period, but increased again at the

314 maturity period; this was significantly higher in XWX-12 in comparison to the other

315 three rice genotypes at the filling period $(* \mathrm{P}<0.05)$. The copy number of aioA gene

316 ranged from $2.35 \times 10^{11} \sim 9.91 \times 10^{11}$ copies $\mathrm{mg}^{-1}$ dry soil of rhizosphere soil at the

317 maturity period, which was significantly higher than that of non-rhizosphere soils.

318 From Fig. 2 (C) and (D), except for the rhizosphere soil of XWX-12, the copy

319 number of As reduction genes (arsC) in rhizosphere and non-rhizosphere soils of the

320 four rice genotype soils showed a consistent trend during the whole growth period,

321 which increased during the joint and filling period, but decreased slightly at

322 maturity. The range of arsC gene copy number in rhizosphere and non-rhizosphere

323 soil during the filling stage was $7.69 \times 10^{10} \sim 9.19 \times 10^{10}$ copies $\mathrm{mg}^{-1}$ dry soil and $6.25 \times 10^{10} \sim 8.69 \times 10^{10}$ copies $\mathrm{mg}^{-1}$ dry soil respectively, which means the rhizosphere 325 environment conditions had little effect on the copy number of arsC genes. At 326 maturity, the copy number of arsC genes in rhizosphere soil of indica rice (XWX-12 and XWX-17) was significantly higher than that of hybrid rice (SY-9586 and

328 FYY-299). Compared with the aioA gene copy number, the arsC copy number 329 decreased by an order of magnitude. In non-rhizosphere soil, the copy number of As 330 methylation genes (arsM) showed a different pattern in different rice genotype soils: 331 the copy number of arsM showed a gradual declining trend that increased 
332 significantly during the maturity period in SY-9586 and XWX-12 rice soils. In 333 comparison, FYY-299 and XWX-17 soils revealed that the copy number of arsM 334 showed a gradual increase throughout the entire growth period. The copy number of 335 arsM ranged from 1.43 to $2.50 \times 10^{13}$ copies $\mathrm{mg}^{-1}$ dry soil at the maturity stage, and 336 there were no genotypic differences throughout the whole growth period. In the 337 rhizosphere soil, except for XWX-12, arsM gene copy numbers in the other three rice 338 genotype soils showed a similar trend during the rice growth period, which firstly 339 increased, but then fell, and then increased reaching the highest value during the 340 maturity period, which ranged from $1.69 \times 10^{13}$ to $3.77 \times 10^{13}$ copies $\mathrm{mg}^{-1}$ dry soil. At 341 the filling stage, the copy number of arsM in the rhizosphere soil of XWX-12 was 342 significantly higher than that of the other three rice genotypes $(* \mathrm{P}<0.05)$. From Fig. 2 , 343 the copy number of arsM was one order of magnitude higher than that of aioA. The 344 copy number of iron reduction genes (Geo) gradually increased in rhizosphere and 345 non-rhizosphere soil from the four rice genotypes during the entire growth period. 346 Independent of rhizosphere or non-rhizosphere soil, the relative abundances of 347 iron-reducing bacteria in indica rice genotype XWX-17 and XWX-12 soils were 348 lower than that of those in hybrid rice SY-9586 and FYY-299 soils after the filling 349 stage.

Fig. 3 presents the RDA analysis between the physicochemical properties of soil 351 solutions and the abundance of soil functional genes. Rice growth period $(\mathrm{P}=0.002)$, $352 \mathrm{EC}(\mathrm{P}=0.012), \mathrm{Fe}(\mathrm{P}=0.002)$, the total As $(\mathrm{P}=0.002)$ and $\mathrm{As}(\mathrm{III})(\mathrm{P}=0.004)$ contents in 353 soil solutions significantly impacted the gene abundances, with explanatory rates 
354 being $70.59 \%, 19.98 \%, 53.36 \%, 61.40 \%$, and $30.0 \%$, respectively. The first and

355 second axes account for $24.25 \%$ and $6.79 \%$ of the total variance respectively. The

356 cosine value of the included angle between superposed gene vector and environmental

357 factors represents the correlation degree, which is the explanatory rate (Zhang et al.,

358 2015) ).

Effects of iron reduction on arsenic functional transformation genes and arsenic speciation transformation in paddy soils

根据图 4 确定铁还原基因与砷还原及甲基化基因的相关关系, 根据图 5 分析土

壤砷功能转化基因 $\operatorname{arsC}$ 、 $\operatorname{arsM}$ 丰度及铁还原基因 $\mathrm{Geo}$ 丰度分别与土壤溶液 $\mathrm{pH}$ 、

Fe、As 和 As(III)含量相关性,

The abundance of iron reduction gene (Geo) in soils was significantly positively correlated with the abundance of As reduction gene $(\operatorname{arsC})(* * * \mathrm{P}<0.001)$ and As methylation gene (arsM) $(* * \mathrm{P}<0.01)$ (Fig. 4), which means that increasing Geo gene

368 abundance led to enhanced arsC and arsM gene abundance; iron reduction in soil 369 therefore promoted As reduction and methylation.

Fig. 5 shows the linear fitting results between $\mathrm{pH}, \mathrm{Fe}$, total As and $\mathrm{As}(\mathrm{III})$ contents in soil solutions and As/Fe functional genes respectively. There were 372 negative correlations between $\mathrm{pH}$ and the gene abundances of arsC, arsM, and Geo, with significant correlation between $\mathrm{pH}$ and $\operatorname{arsC}$ gene abundance $(* * \mathrm{P}<0.01)$. The contents of Fe, As and As(III) in soil solutions were significantly positively correlated

375 with Geo and $\operatorname{arsM}(* * * \mathrm{P}<0.001)$, and $\operatorname{arsC}(* * \mathrm{P}<0.01)$ abundances. The results 
revealed that in flooded paddy soils, iron reduction is gradually enhanced, iron (hydrogen) oxide dissolves and Fe/As is released into the soil solution, resulting in the abundance and activity of As reducing and methylating microorganisms. The enhanced abundance of ars $\mathrm{C}$ and arsM genes promoted the reduction and methylation process of As, which led to increasing As(III) concentrations in soil solutions. The mobility and speciation of As in soils may be principally driven by microorganisms, especially those involved in the biological reduction process of iron (References).

\section{Effect of iron reduction on arsenic uptake and speciation in rice}

Fig. 6 shows the effect of microbial iron reduction processes on As accumulation in different rice tissues and in iron plaque. Geo gene abundance was significantly positively correlated with As concentration in roots and grains $(* \mathrm{P}<0.05)$. The concentrations of $\mathrm{As}(\mathrm{III})$ and total As in grains were significantly negatively correlated with abundance of arsC genes $(* \mathrm{P}<0.05)$. In order to clarify the mechanism for the effect of functional genes on the concentrations of total As and grain As(III) in rice, considering that iron plaque was one of the main factors affecting the uptake and speciation of As, we fitted the correlation between functional genes and the concentrations of Fe/As in root surface iron plaque (Fig. $6(\mathrm{G})$ and $(\mathrm{H})$ ). It can be seen from the figure that the concentrations of DCB-extracted Fe/As were positively correlated with $\operatorname{arsC}(\mathrm{R}=0.43, \mathrm{R}=0.18$, respectively), indicating that As reducing processes may promote formation of iron plaque on roots as well as sequestration of As, consequently reducing As uptake in rice. 

iron-reducing bacteria, formed iron plaque due to the ROL effect of rice. Arsenite may then be removed from the soil solution by iron plaque, which then releases the iron minerals coupled with As. Enhancement of iron reduction gene abundance in soil may increase the abundance of arsC and arsM genes, which promote the release, reduction and methylation of As in soil solution, thereby affecting the accumulation of soil were slow-released into the soil solution, resulting in an increase in EC.

417 Subsequently, with an increase in soil $\mathrm{pH}$, alkali metals in the solution precipitate and 418 the concentration of $\mathrm{H}^{+}$decrease, causing a rapid decline in EC in solution. Following 419 this, the continuous decrease in soil Eh promotes dissolution of iron (hydroxide) 
420 oxides, and the release and transformation of As species, resulting in an increase of 421 ion concentrations in the soil solution, which increases EC (adding references). 422 During the entire rice growth period, the abundances of $\mathrm{As} / \mathrm{Fe}$ reduction genes (arsC and Geo) were very high and presented a gradual increasing trend. Meanwhile, arsC gene abundance in the rhizosphere was higher than that in the non-rhizosphere, as well as the changing trend of total As and As(III) concentrations in soil solutions. However, Geo gene abundance in the rhizosphere was lower than that of non-rhizosphere soil solutions. The abundance of Geo gene in soil was significantly correlated with $\mathrm{Fe}$ and total As concentrations in soil solutions (***P $<0.001)$, which indicated that microbial processes were the main driving mechanism for the release of $\mathrm{As} / \mathrm{Fe}$ in soil. In addition, $\mathrm{pH}$ was significantly correlated with $\mathrm{Fe}$ and $\mathrm{As}(\mathrm{III})$ concentration, both in rhizosphere and non-rhizosphere soil solutions, suggesting that $\mathrm{pH}$ was also an important factor in promoting As/Fe release. Flooded conditions led to an increase in soil $\mathrm{pH}$ and the decrease of Eh. Studies have shown that when Eh falls below $+100 \mathrm{mV}$, iron (hydroxide) oxides are reductively dissolved, and at the same reductive microorganisms increase (Somenahally et al., 2011; Yamaguchi et al., 2014).

437 There was a significant correlation between Fe and total As concentrations in 438 rhizosphere and non-rhizosphere soil solutions ( $* \mathrm{P}<0.05)$, because FeRB can couple 439 the oxidation process of organic matter and obtain energy by reducing iron (hydrogen) 440 oxides (Somenahally et al., 2011). The reductive dissolution of iron (hydrogen) oxides 441 caused the majority of adsorbed As to be released into the soil solution, as well as 
insoluble Fe (III) being reduced to soluble Fe( II ) ions (Somenahally et al., 2011).

Studies have revealed that dissimilatory iron reduction processes are ubiquitous in paddy soils, with iron production accounting for $24 \%$ of the total reduced iron (Hori et al., 2010). On the other hand, it can be seen from Fig. $3(\mathrm{G}),(\mathrm{H}),(\mathrm{I})$ and (J) that under flooded conditions, the majority of As species in rhizosphere and non-rhizosphere soil solutions was As(III), accounting for $94 \%$ of total As. Under anaerobic conditions, the parameters of soil $\mathrm{Eh}, \mathrm{DOC}, \mathrm{EC}, \mathrm{SO}_{4}{ }^{2-}$ and total $\mathrm{As} / \mathrm{Fe}$ concentration including As(III) in soil solutions, significantly affected the relative abundance of arsC genes and changed the abundance of As reductive microorganisms (Wang et al., 2017; Zhang et al., 2015; Zheng et al., 2017). In this study, during the whole rice growth period, $\mathrm{pH}, \mathrm{EC}$, total $\mathrm{As} / \mathrm{Fe}$ concentration of soil solutions increased, relative abundance of arsC genes increased rapidly, and the microbial activity of As reductive microorganisms was enhanced, which all resulted in the conversion of $\mathrm{As}(\mathrm{V})$ to $\mathrm{As}(\mathrm{III})$, so that the majority of As in soil solution was As(III). There are two common approaches to the As reduction process in rice soil. Firstly, the reductive dissolution of iron (hydrogen) oxides leads to the release of adsorbed As( V) into solution, and then As( V ) is reduced to As(III) by As reducting bacteria; secondly, adsorbed As( V) was directly reduced to As(III) on the surface of iron (hydrogen) oxides, and then As(III), which has a weaker adsorption capacity, is then released into solution (Zhang et al., 2015). Our results show that the relative abundance of Geo genes in indica rice (XWX-17 and XWX-12) soil is lower than that of hybrid rice (SY-9586 and FYY-299), in both rhizosphere and non-rhizosphere soils, after rice 
464 growth to the filling stage. Furthermore, the abundance of Geo genes in 465 non-rhizosphere soils was higher than that of rhizosphere soils, indicating that aerobic 466 conditions in the rhizosphere decreased the abundance and activity of Fe reductive 467 microorganisms.

468 Under anaerobic conditions, a large amount of iron (hydroxide) oxide in the soil 469 was reduced to $\mathrm{Fe}$ ( II ). Due to aerobic conditions in the rhizosphere, $\mathrm{Fe}$ ( II ) migrated 470 by diffusion in the non-rhizosphere soil solution and was oxidized to Fe(III), which 471 then is deposited on the root as an iron plaque (Pan et al., 2016). The soils around rice 472 roots can therefore be divided into three areas: 1) the iron plaque region attached to 473 the root surface directly, which has the strongest oxidation, 2) the rhizosphere soil 474 region adjacent to the rice root, which is affected by the aerobic conditions in the rice 475 rhizosphere and the reductive condition caused by the flooded environment, and 3) 476 the non-rhizosphere soil region, which was less affected by ROL, and mainly 477 dominated by reductive conditions (Wu et al., 2016). All three regions have their own 478 unique biochemical properties (Somenahally et al., 2011). A lack of aerated tissues in 479 immature rice roots and decreasing Eh in deeper rhizosphere soils, means that iron 480 plaque could not adhere to the root surface and fix As (Fig. 1 (G))(Wang et al., 2015; 481 Yamaguchi et al., 2014). Our results show that the concentration of As(III) of hybrid 482 rice in rhizosphere soil solutions at filling and maturity stages was higher than that of 483 indica rice (Fig. 1(I)). Table 3 reveals that there was a significant positive correlation $484(\mathrm{P}<0.05)$ between As $(\mathrm{III})$ concentration in rhizosphere soils and As concentration in 485 iron plaque, with a correlation coefficient of 0.602. Yamaguchi et al. (2014) found that 
there was no dissolved As( $V)$ in soil solutions under anaerobic conditions, so As

mainly existed in trivalent form, however, a small part of As(III) was converted into

As $(V)$ under the action of rhizosphere ROL, thus, the speciation of As in the iron

plaque was likely to be determined by the Eh of rice soil (Yamaguchi et al., 2014). In

490

addition, there was a significant positive correlation between the content of As(III) in

rhizosphere soil solutions and the content of $\mathrm{Fe}$ in iron plaque $(* \mathrm{P}<0.05)$, with a correlation coefficient of 0.708 , indicating that As(III) could affect the formation of iron plaque, which was consistent with Lee et al. (Lee et al., 2013).

Arsenic biotransformation mediated by microorganisms significantly affected As environmental behavior and bioavailability in paddy soils. Studies have shown that As metabolic genes are mainly derived from the Proteobacteria, Gemmatimonadales and Firmicutes in rice rhizosphere soils (Das et al., 2017). There are many factors affecting the activities of arsenic-metabolizing microorganisms, including soil $\mathrm{pH}, \mathrm{EC}$, total carbon, nitrogen, As, iron, $\mathrm{C} / \mathrm{N}$ ratio, sulfate ions and nitrate ions (Zhang et al., 2015). In addition, rice rhizosphere conditions can also play an important role in the physicochemical properties of soils, microbial compositions and activities in paddy soils. For example, the mucus, polysaccharides, amino acids and organic acids secreted by roots can increase microbial abundance and change microbial community structure (Zhang et al., 2015). The results showed that the aioA gene abundance in the rhizosphere was higher than that in non-rhizosphere soils (Fig. 2(A)), which was consistent with the research results of Jia et al. (Jia et al., 2014). Compared with 
roots, was more suitable to the survival of As-oxidative microorganisms. Therefore, aioA gene abundance in rhizosphere soils was higher than non-rhizosphere soils; in addition, we found the aioA gene rhizosphere abundance with SY-9586, was significantly lower than that of the other three rice genotypes (Fig. 2(A)). This may be due to the lower radial oxygen loss of its root. Total As and As(III) content in the rhizosphere soil solution of SY-9586 was also higher than that of the other three rice genotypes (Fig. 1(G), (I)), which indicated that the rhizosphere could affect the abundance of As oxidative microorganisms, and change the bioavailability of As and plant As uptake. Under sterile conditions, As(III) is hardly oxidized to As(V), relying only on the chemical oxidation ability of $\mathrm{O}_{2}$ (Rhine et al., 2005). Therefore the enhancement of microbial-mediated As oxidation in the rhizosphere is effective for reducing As availability and plant As uptake. The arsC gene abundance in the rhizosphere was higher than that of non-rhizosphere soils and indica rice with high radial oxygen loss was higher than that of hybrid rice (Fig. 2(C), (D)). Jia et al. (2014) found that arsC gene abundance in the rhizosphere was higher than $50.8 \%$ of non-rhizosphere soils (Jia et al., 2014), which was consistent with our results. Furthermore, our research reveals that there was a certain amount of methylated As in rice plants, especially in grains, accounting for up to $39 \%$ of the total As. Rice does not have the ability to methylate As, and the methylated As accumulated in the plants was derived from soil (Jia et al., 2013b). Methylated As in soil was derived from human activities, atmospheric deposition and microbial methylation, of which the third is the main source (Huang et al., 2011). Studies have shown that there is no As 
is a biological process. Furthermore, As methylation by microorganisms occured quickly, especially when the soil was in an anaerobic state (Huang and Matzner, 2006). Current research shows that arsM gene abundance was higher than that of aioA and $\operatorname{arsC}$ by one and two orders of magnitude, respectively. Except for the rice 535 genotype of XWX-17, arsM gene abundance in the rhizosphere was higher than that 536 of non-rhizosphere soils for the other three rice genotypes, and generally showed an 537 increasing trend with the continuation of growth period. However, there was no DMA and MMA detected in pore waters, which may be due to several reasons. Firstly, the abundance and organic As concentration in soil were associated with $\mathrm{pH}$ into positive and negative correlations, respectively, with the greater activity of microbial As 543 methylation under acid condition, however the $\mathrm{pH}$ of the experimental soil ranged 544 from $7.3 \sim 8.5$ (Zhao et al., 2013). Jia et al. found that the change of rhizosphere 545 environment and addition of rice straw increased the abundance of arsM genes 546 significantly, possibly because of the improved rhizosphere environment and the 547 increase of DOC, which promoted the activities of As methylating microorganisms 548 (Shimizu et al., 2011). In flooded soils, the reductive dissolution of iron (hydrogen) 549 oxides caused by iron-reducing bacteria, resulted in a massive release of arsenic into 550 the soil solution (Cummings et al., 1999), which promoted the accumulation of 551 organic As in grains (Huang and Matzner, 2006). Studies showed that iron-reducing 
552 bacteria existed widely in paddy soil, and were mainly anaerobic bacteria (Hori et al., 553 2010). Current studies show that the Geo gene abundance of rhizosphere soil is lower 554 than that of the non-rhizosphere, and with continuous flooding of growth periods, 555 both Geo gene rhizosphere and non-rhizospheres showed gradually increasing trends, 556 which was consistent with the research of Somenahally et al. (Somenahally et al., 557 2011; Somenahally et al., 2011).

Our results indicated that the flooded soil conditions increased the abundance of

559 Geo genes. With the enhancement of iron reduction processes, the abundance of arsC 560 and arsM genes increased, which promoted the reduction and release of As in soil 561 solution and the accumulation of DMA in rice grains (Fig. 5 and 6). Studies have 562 revealed that there are a large number of bacteria and fungi, which contain the aioA, 563 arsC, arsM and Geo functional genes, such as Proteobacteria $(\alpha-, \beta-, \gamma-$ and $564 \delta$-Proteobacteria, etc.) (Zhang et al., 2015). As a result of iron reduction, the increase 565 in As may trigger microbial detoxification and promote methylation of As through the 566 Challenger pathway, $\mathrm{As}(\mathrm{V}) \rightarrow \mathrm{As}(\mathrm{III}) \rightarrow \mathrm{MMA}(\mathrm{V}) \rightarrow \mathrm{MMA}(\mathrm{III}) \rightarrow \mathrm{DMA}(\mathrm{V}) \rightarrow$ $567 \mathrm{DMA}(\mathrm{III}) \rightarrow \mathrm{TMAO}(\mathrm{V}) \rightarrow \mathrm{TMA}(\mathrm{III})$, resulting in an increase of arsC and arsM gene 568 abundance (Somenahally et al., 2011; Ye et al., 2012). Our results also indicated iron 569 plaque formation and As fixation were found to have an extremely significant positive 570 correlation $(* * \mathrm{p}<0.01)$ with arsC gene abundance (Fig. 6), and have a significant 571 positive correlation $(* \mathrm{p}<0.05)$ with $\mathrm{As}(\mathrm{III})$ in the soil solution (Table 3 ). This may 572 have enhanced arsC gene abundance leading to a large increase in As(III) content in 573 soil solution, consequently promoting the formation of iron plaque and As fixation. 
574 Yamaguchi et al. found that iron plaque mainly adsorbed As(III) under anaerobic 575 conditions, reducing the absorption of As(III) in rice. However, the inhibitory effect of 576 iron plaque on As(III) absorption in rice is much stronger than the increase of As(III) 577 concentration in soil solution, resulting in arsC gene abundance being significantly 578 negatively correlated with total As in rice and As(III) in grain. Iron plaque had a weak 579 DMA adsorption capacity, and rice could not adsorb methyl As, so the increase of 580 arsM gene abundance may promote the accumulation of DMA in rice grains.

581 土壤淹水条件下, 铁还原菌还原土壤中的铁（氢）氧化物释放的二价亚铁离子, 582 在水稻根际渗氧作用下形成铁膜, 吸收土壤溶液中的三价砷离子, 同时释放出铁 583 矿物上耦合的砷。淹水条件下土壤中铁还原基因丰度的提高, 导致 $\operatorname{arsC}$ 和 $\operatorname{arsM}$ 584 基因丰度升高, 从而促进 As 在土壤溶液中的释放、还原和甲基化, 进而影响水 585 稻植株籽粒中三价砷及 DMA 的累计。

$586 \quad$ Under flooded conditions, iron-reducing bacteria caused ferrous ion release from 587 iron (hydrogen) oxides, but ferrous ions could form iron plaque under the ROL effect 588 of rice roots, and iron plaque further absorbed As(III) in the soil solution (Fig. 7). 589 Meanwhile, iron-reducing bacteria also caused iron minerals to release As (Fig. 7). 590 The iron reduction gene abundance in soils was significantly correlated with the 591 abundance of arsenic reduction gene arsC and arsenic methylation gene arsM (Fig. 4).

592 This demonstrated that the iron reduction process causing the release, reduction and 593 methylation of As in soil solution, was thereby affecting the accumulation of As(III) 594 and DMA in rice grains. 


\section{CONCLUSION}

1) During the rice growth period, the $\mathrm{pH}$ range of rhizosphere and non-rhizosphere

598 soil solutions ranged from 7.41 to 8.80 , both of which increased and then

599 subsequently decreased. The EC range was $116.3-820.0 \mathrm{mS} / \mathrm{cm}$, during the tillering 600 stage and early stage of filling, showing a significant upward trend, which then 601 decreased significantly. The contents of Fe, As and As(III) in the rhizosphere and 602 non-rhizosphere soil solution of rice showed similar trends, all of which showed a 603 gradual increase; Fe increased from 0.78 to $72.21 \mathrm{mg} / \mathrm{L}$, As ranged from 73.5 to 453.0 $604 \mu \mathrm{g} / \mathrm{L}$ and As(III) ranged from 62.1 to $340.2 \mu \mathrm{g} / \mathrm{L}$. Iron content was significantly 605 positively correlated with As and As(III) contents $(* * * \mathrm{p}<0.001)$, As content and As(III) 606 content also showed a significant positive correlation $\left({ }^{*} \mathrm{p}<0.05\right)$.

607 2) With the growth of rice, aioA gene abundance decreased gradually, and the 608 abundance of arsC, arsM and Geo genes increased gradually. The abundance of aioA, 609 ars C and arsM genes in rhizosphere soils was higher than that in non-rhizosphere soils. 610 The abundance of Geo genes in the rhizosphere was lower than that in 611 non-rhizosphere soils. Correlation analysis showed that Geo gene abundance was 612 significantly positively correlated with arsC $(* * * \mathrm{p}<0.001)$ and arsM gene abundance 614 significantly positively correlated with $\mathrm{Geo}$, $\operatorname{arsC}$ and $\operatorname{arsM}(* * \mathrm{p}<0.01)$. This 615 indicated that the cascade of Fe/As in soil solution reduced and dissolved by reduction 616 processes, may trigger the detoxification mechanism of As, increase the abundance of 617 arsC and arsM genes, firstly reducing $\mathrm{As}(\mathrm{V})$ as $\mathrm{As}(\mathrm{III})$, and then by methylation 
618 processes to become DMA and MMA. The increase of As(III) concentration in the 619 soil solution significantly promoted the formation of iron plaque. The inhibitory effect 620 of iron plaque on As(III) absorption was much stronger than the promoting effect of 621 arsC genes on $\mathrm{As}(\mathrm{III})$ concentration in the soil solution. Therefore, arsC gene 622 abundance was significantly negatively correlated with total arsenic and As(III) in rice 623 grains $(* \mathrm{P}<0.05)$. The adsorption effect of iron plaque on DMA was very weak, so the 624 abundance of arsM genes may have significantly promoted the accumulation of DMA 625 in rice grains. RDA analysis revealed that rice growth period $(* * p<0.01)$, EC $626(* \mathrm{P}<0.05), \mathrm{Fe}(* * \mathrm{p}<0.01) / \mathrm{As}(* * \mathrm{p}<0.01)$ concentrations and $\mathrm{As}(\mathrm{III})(* * \mathrm{p}<0.01)$ are 627 the main factors affecting soil arsenic metabolism and iron reduction gene abundance, 628 whereas, the effects of the rhizosphere environment and rice genotypes were not 629 significant. 


\section{References:}

Ackermann, J., Vetterlein, D., Kuehn, T., Kaiser, K., Jahn, R., 2010. Minerals controlling arsenic distribution in floodplain soils. EUROPEAN JOURNAL OF SOIL SCIENCE 61, 588-598.

Bahar, M.M., Megharaj, M., Naidu, R., 2012. Arsenic bioremediation potential of a new arsenite-oxidizing bacterium Stenotrophomonas sp. MM-7 isolated from soil. BIODEGRADATION 23, 803-812.

Bais, H., Weir, T., Perry, L., Gilroy, S., Vivanco, J., 2006. The Role of Root Exudates in Rhizosphere Interactions with Plants and Other Organisms. Annual Review of Plant Biology 57, 233-266.

Borch, T., Kretzschmar, R., Kappler, A., Cappellen, P.V., Campbell, K., 2010. Biogeochemical Redox Processes and their Impact on Contaminant Dynamics. ENVIRONMENTAL SCIENCE \& TECHNOLOGY 44, 15-23.

Charlet, L., Polya, D., 2006. Arsenic in shallow, reducing groundwaters in southern Asia: An environmental health disaster. Elements 2, 91-96.

Cummings, D.E., Caccavo, F.J., Fendorf, S., Rosenzweig, R.F., 1999. Arsenic mobilization by the dissimilatory Fe(III)-reducing bacterium Shewanella alga BrY. Environmental Science \& Technology Easton Pa 33, 723-729.

Das, S., Chou, M., Jean, J., Yang, H., Kim, P.J., 2017. Arsenic-enrichment enhanced root exudates and altered rhizosphere microbial communities and activities in hyperaccumulator Pteris vittata. JOURNAL OF HAZARDOUS MATERIALS 325, 279-287.

Doušová, B., Lhotka, M., Grygar, T., Machovič, V., Herzogová, L., 2011. In situ co-adsorption of arsenic and iron/manganese ions on raw clays. APPLIED CLAY SCIENCE 54, 166-171.

Frost, F., Muller, T., Petersen, H., Thomson, B., Tollestrup, K., 2003. Identifying US populations for the study of health effects related to drinking water arsenic. Journal of Exposure Analysis \& Environmental Epidemiology 13, 231-239.

Guo, H., Ren, Y., Liu, Q., Zhao, K., Li, Y., 2013. Enhancement of Arsenic Adsorption during Mineral Transformation from Siderite to Goethite: Mechanism and Application. ENVIRONMENTAL SCIENCE \& TECHNOLOGY 47, 1009-1016.

Honma, T., Ohba, H., Kaneko-Kadokura, A., Makino, T., Nakamura, K., Katou, H., 2016. Optimal Soil Eh, $\mathrm{pH}$, and Water Management for Simultaneously Minimizing Arsenic and Cadmium Concentrations in Rice Grains. ENVIRONMENTAL SCIENCE \& TECHNOLOGY 50, 178-4185.

Hori, T., Alexandra, M., Igarashi, Y., Conrad, R., Friedrich, M.W., 2010. Hori T , Alexandra Müller, Igarashi $\mathrm{Y}$, et al. Identification of iron-reducing microorganisms in anoxic rice paddy soil by ${ }^{13} \mathrm{C}$-acetate probing. ISME Journal 4, 267-278.

Hori, T., Muller, A., Igarashi, Y., Conrad, R., Friedrich, M.W., 2010. Identification of iron-reducing microorganisms in anoxic rice paddy soil by 13C-acetate probing. ISME Journal 4, 267-278.

Huang, J., Hu, K., Decker, B., 2011. Organic arsenic in the soil environment: speciation, occurrence, transformation, and aadsorption behavior. Water, Air, \& Soil Pollution 219, 401-415.

Huang, J.H., Matzner, E., 2006. Dynamics of organic and inorganic arsenic in the solution phase of an acidic fen in Germany. GEOCHIMICA ET COSMOCHIMICA ACTA 70, 2023-2033.

Huang, J.H., Voegelin, A., Pombo, S.A., Lazzaro, A., Zeyer, J., Kretzschmar, R., 2011. Influence of arsenate adsorption to ferrihydrite, goethite, and boehmite on the kinetics of arsenate reduction by 
Shewanella putrefaciens strain CN-32. ENVIRONMENTAL SCIENCE \& TECHNOLOGY 45, 7701-7709.

Inskeep, W.P., Macur, R.E., Hamamura, N., Warelow, T.P., Ward, S.A., Santini, J.M., 2007. Detection, diversity and expression of aerobic bacterial arsenite oxidase genes. ENVIRONMENTAL MICROBIOLOGY 9, 934-943.

Jia, Y., Huang, H., Chen, Z., Zhu, Y.G., 2014. Arsenic uptake by rice is influenced by microbe-mediated arsenic redox changes in the rhizosphere. ENVIRONMENTAL SCIENCE \& TECHNOLOGY 48, 1001-1007.

Jia, Y., Huang, H., Zhong, M., Wang, F.H., Zhang, L.M., Zhu, Y.G., 2013a. Microbial arsenic methylation in soil and rice rhizosphere. ENVIRONMENTAL SCIENCE \& TECHNOLOGY 47, 3141-3148.

Jia, Y., Huang, H., Zhong, M., Wang, F.H., Zhang, L.M., Zhu, Y.G., 2013b. Microbial arsenic methylation in soil and rice rhizosphere. ENVIRONMENTAL SCIENCE \& TECHNOLOGY 47, 3141-3148.

Jiang, S., Lee, J., Kim, D., Kanaly, R., Kim, M., Hur, H., 2013. Differential arsenic mobilization from As-bearing ferrihydrite by iron-respiring Shewanella strains with different arsenic-reducing activities. ENVIRONMENTAL SCIENCE \& TECHNOLOGY 47, 8616-8623.

Khan, M.A., Islam, M.R., Panaullah, G.M., Duxbury, J.M., Jahiruddin, M., Loeppert, R.H., 2010. Accumulation of arsenic in soil and rice under wetland condition in Bangladesh. PLANT AND SOIL, 263-274.

Khush, G., 2013. Strategies for increasing the yield potential of cereals: case of rice as an example. PLANT BREEDING 132, 433-436.

Kim, E.J., Hwang, B., Baek, K., 2015. Effects of natural organic matter on the coprecipitation of arsenic with iron. ENVIRONMENTAL GEOCHEMISTRY AND HEALTH 37, 1029-1039.

Lee, C., Hsieh, Y., Lin, T., Lee, D., 2013. Iron plaque formation and its effect on arsenic uptake by different genotypes of paddy rice. PLANT AND SOIL 363, 231-241.

Pan, W., Wu, C., Xue, S., Hartley, W., 2016. Arsenic dynamics in the rhizosphere and its sequestration on rice roots as affected by root oxidation. JOURNAL OF ENVIRONMENTAL SCIENCES, 892-899.

Rhine, E.D., Garcia-Dominguez, E., Phelps, C.D., Young, L.Y., 2005. Environmental microbes can speciate and cycle arsenic. ENVIRONMENTAL SCIENCE \& TECHNOLOGY 39, 9569-9573.

Seyfferth, A.L., McCurdy, S., Schaefer, M.V., Fendorf, S., 2014. Arsenic Concentrations in Paddy Soil and Rice and Health Implications for Major Rice-Growing Regions of Cambodia. ENVIRONMENTAL SCIENCE \& TECHNOLOGY 48, 4699-4706.

Sforna, M.C., Philippot, P., Somogyi, A., van Zuilen, M.A., Medjoubi, K., Schoepp-Cothenet, B., Nitschke, W., Visscher, P.T., 2014. Evidence for arsenic metabolism and cycling by microorganisms 2.7 billion years ago. Nature Geoscience 7, 811-815.

Shi, Q., Jing, C., Meng, X., 2018. Competing Interactions of As Adsorption and Fe(III) Polymerization during Ferric Coprecipitation Treatment. ENVIRONMENTAL SCIENCE \& TECHNOLOGY.

Shimizu, M., Arai, Y., Sparks, D.L., 2011. Multiscale Assessment of Methylarsenic Reactivity in Soil. 2. Distribution and Speciation in Soil. ENVIRONMENTAL SCIENCE \& TECHNOLOGY 45, 4300-4306.

Singh, R., Singh, S., Parihar, P., Singh, V.P., Prasad, S.M., 2015. Arsenic contamination, consequences and remediation techniques: A review. ECOTOXICOLOGY AND ENVIRONMENTAL SAFETY 112 , 247-270. 
Somenahally, A.C., Hollister, E.B., Loeppert, R.H., Yan, W., Gentry, T.J., 2011. Microbial communities in rice rhizosphere altered by intermittent and continuous flooding in fields with long-term arsenic application. Soil Biology and Biochemistry 43, 1220-1228.

Somenahally, A.C., Hollister, E.B., Yan, W., Gentry, T.J., Loeppert, R.H., 2011. Water management impacts on arsenic speciation and iron-reducing bacteria in contrasting rice-rhizosphere compartments. ENVIRONMENTAL SCIENCE \& TECHNOLOGY 45, 8328-8335.

Stroud, J.L., Norton, G.J., Islam, M.R., Dasgupta, T., White, R.P., 2011. The dynamics of arsenic in four paddy fields in the Bengal delta. ENVIRONMENTAL POLLUTION, 947-953.

Sun, Y., Polishchuk, E.A., Radoja, U., Cullen, W.R., 2004. Identification and quantification of arsC genes in environmental samples by using real-time PCR. JOURNAL OF MICROBIOLOGICAL METHODS 58, 335-349.

Takahashi, Y., Minamikawa, R., Hattori, K.H., Kurishima, K., Kihou, N., 2004. Arsenic behavior in paddy fields during the cycle of flooded and non-flooded periods. ENVIRONMENTAL SCIENCE \& TECHNOLOGY 38, 1038-1044.

Tufano, K.J., Fendorf, S., 2008. Confounding impacts of iron reduction on arsenic retention. ENVIRONMENTAL SCIENCE \& TECHNOLOGY 42, 4777-4783.

Wang, N., Xue, X., Juhasz, A.L., Chang, Z., Li, H., 2017. Biochar increases arsenic release from an anaerobic paddy soil due to enhanced microbial reduction of iron and arsenic. ENVIRONMENTAL POLLUTION 220, 514e-522e.

Wang, X., Peng, B., Tan, C.Y., Ma, L., Rathinasabapathi, B., 2015. Recent advances in arsenic bioavailability, transport, and speciation in rice. Environ. Sci. Pollut. Res. Int. 22, 5742-5750. Wu, C., Zou, Q., Xue, S.G., Pan, W.S., Huang, L., Hartley, W., Mo, J.Y., Wong, M.H., 2016. The effect of silicon on iron plaque formation and arsenic accumulation in rice genotypes with different radial oxygen loss (ROL). ENVIRONMENTAL POLLUTION 212, 27-33

Wu, C., Huang, L., Xue, S., Pan, W., Zou, Q., Hartley, W., Wong, M., 2017. Oxic and anoxic conditions affect arsenic (As) accumulation and arsenite transporter expression in rice. CHEMOSPHERE 168, 969-975.

.Yamaguchi, N., Nakamura, T., Dong, D., Takahashi, Y., Amachi, S., Makino, T., 2011. Arsenic release from flooded paddy soils is influenced by speciation, Eh, pH, and iron dissolution. CHEMOSPHERE 83, 925-932.

Yamaguchi, N., Ohkura, T., Takahashi, Y., Maejima, Y., Arao, T., 2014. Arsenic Distribution and Speciation near Rice Roots Influenced by Iron Plaques and Redox Conditions of the Soil Matrix. ENVIRONMENTAL SCIENCE \& TECHNOLOGY 48, 1549-1556.

Yamaguchi, N., Ohkura, T., Takahashi, Y., Maejima, Y., Arao, T., 2014. Arsenic distribution and speciation near rice roots influenced by iron plaques and redox conditions of the soil matrix. ENVIRONMENTAL SCIENCE \& TECHNOLOGY, 1549-1556.

Yamamura, S., Amachi, S., 2014. Microbiology of inorganic arsenic: From metabolism to bioremediation. JOURNAL OF BIOSCIENCE AND BIOENGINEERING 118, 1-9.

Yamamura, S., Yamamoto, N., Ike, M., Fujita, M., 2005. Arsenic extraction from solid phase using a dissimilatory arsenate-reducing bacterium. Journal of Bioscience \& Bioengineering 100, 219-222.

Yan, B., Methé, B.A., Lovley, D.R., Krushkal, J., 2004. Computational prediction of conserved operons and phylogenetic footprinting of transcription regulatory elements in the metal-reducing bacterial family Geobacteraceae. JOURNAL OF THEORETICAL BIOLOGY 230, 133-144. Ye, J., Rensing, C., Rosen, B.P., Zhu, Y., 2012. Arsenic biomethylation by photosynthetic organisms. 
TRENDS IN PLANT SCIENCE 17, 155-162.

Zhang, J., Zhou, W., Liu, B., He, J., Shen, Q., Zhao, F., 2015. Anaerobic Arsenite Oxidation by an Autotrophic Arsenite-Oxidizing Bacterium from an Arsenic-Contaminated Paddy Soil. ENVIRONMENTAL SCIENCE \& TECHNOLOGY.

Zhang, S., Zhao, F., Sun, G., Su, J., Yang, X., Li, H., Zhu, Y., 2015. Diversity and Abundance of Arsenic Biotransformation Genes in Paddy Soils from Southern China. ENVIRONMENTAL SCIENCE \& TECHNOLOGY, 4138-4146.

Zhao, F., Harris, E., Yan, J., Ma, J., Wu, L., Liu, W., McGrath, S.P., Zhou, J., Zhu, Y., 2013. Arsenic Methylation in Soils and Its Relationship with Microbial arsM Abundance and Diversity, and As Speciation in Rice. ENVIRONMENTAL SCIENCE \& TECHNOLOGY 47, 7147-7154.

Zhao, F.J., Ma, Y., Zhu, Y.G., Tang, Z., Mcgrath, S.P., 2015. Soil contamination in China: current status and mitigation strategies. Environmental Science \& Technology 49, 750.

Zhao, F.J., McGrath, S.P., Meharg, A.A., 2010. Arsenic as a food chain contaminant: mechanisms of plant uptake and metabolism and mitigation strategies. Annual Review of Plant Biology 61, 535-559.

Zheng, C., Wang, Y., Jiang, X., Fu, D., Xia, D., Wang, H., Dong, G., Li, Q., 2017. Dual roles of AQDS as electron shuttles for microbes and dissolved organic matter involved in arsenic and iron mobilization in the arsenic-rich sediment. SCIENCE OF THE TOTAL ENVIRONMENT 574, 1684-1694.

Zhu, Y.G., Williams, P.N., Meharg, A.A., 2008. Exposure to inorganic arsenic from rice: a global health issue? ENVIRONMENTAL POLLUTION 154, 169-171.

Zhu, Y.G., Yoshinag, M., Zhao, F.J., Rosen, B.P., 2014. Earth Abides Arsenic Biotransformations. Annu. Rev. Earth Planet. Sci. 42, 443-467.

Zou, Q., An, W., Wu, C., Li, W., Fu, A., Xiao, R., Chen, H., Xue, S., 2017. Red mud-modified biochar reduces soil arsenic availability and changes bacterial composition. Environmental Chemistry Letters $15,1-8$.

Table 1 Correlation matrix of physicochemical variables of soil solution samples in the rhizosphere of rice $(\mathrm{n}=84)$

\begin{tabular}{llllll}
\hline & $\mathrm{pH}$ & $\mathrm{EC}$ & $\mathrm{Fe}$ & $\mathrm{As}$ & $\mathrm{As}(\mathrm{III})$ \\
\hline $\mathrm{pH}$ & & & & & \\
$\mathrm{EC}$ & -0.101 & & & & \\
$\mathrm{Fe}$ & $-0.223^{*}$ & $-0.455^{* *}$ & & & \\
$\mathrm{As}$ & -0.138 & $0.375^{* *}$ & $0.473^{* *}$ & & \\
$\mathrm{As}(\mathrm{III})$ & $-0.503^{* *}$ & 0.203 & $0.673^{* *}$ & $0.447^{* *}$ & \\
\hline
\end{tabular}

*indicated that there is a significant difference $(* \mathrm{P}<0.05)$

${ }^{* *}$ indicated that there is a fearfully significant difference $(* * \mathrm{P}<0.01)$ 
800

801

802

803

804

805 Table 2 Proportions of As species in root, straw, husk and grain of different rice

806 genotypes ( mean $\pm \mathrm{SD}, \mathrm{n}=3$ )

\begin{tabular}{|c|c|c|c|c|c|c|}
\hline varieties & part & $\begin{array}{l}\mathrm{As}(\mathrm{III}) \\
\text { concentration } \\
(\mathrm{mg} / \mathrm{kg})\end{array}$ & $\begin{array}{l}\mathrm{As}(\mathrm{V}) \\
\text { concentration } \\
(\mathrm{mg} / \mathrm{kg})\end{array}$ & $\begin{array}{l}\text { DMA } \\
(\mathrm{mg} / \mathrm{kg})\end{array}$ & $\begin{array}{l}\text { MMA } \\
(\mathrm{mg} / \mathrm{kg})\end{array}$ & $A s^{\mathrm{a}}$ \\
\hline SY-9586 & \multirow{4}{*}{ root } & $123.3 \pm 3.6 \mathrm{ab}$ & $117.5 \pm 4.3 \mathrm{a}^{\prime}$ & $16.7 \pm 0.7 \mathrm{~A}$ & $22.7 \pm 3.8 \mathrm{~A}^{\prime}$ & 280.3 \\
\hline FYY-299 & & $128.9 \pm 19.3 \mathrm{ab}$ & $114.3 \pm 4.7 \mathrm{a}^{\prime}$ & $23.4 \pm 5.2 \mathrm{AB}$ & $16.7 \pm 2.9 \mathrm{~B}^{\prime}$ & 283.4 \\
\hline XWX-17 & & $162.2 \pm 71.9 \mathrm{a}$ & $120.6 \pm 5.9 a^{\prime}$ & $30.7 \pm 7.1 \mathrm{~B}$ & $22.7 \pm 5.5 \mathrm{~A}^{\prime}$ & 280.3 \\
\hline XWX-12 & & $95.2 \pm 14.6 \mathrm{~b}$ & $131.1 \pm 10.0 \mathrm{~b}$ & $17.6 \pm 8.8 \mathrm{~A}$ & $15.8 \pm 2.9 \mathrm{~B}^{\prime}$ & 259.5 \\
\hline SY-9586 & \multirow{4}{*}{ straw } & $12.1 \pm 9 \mathrm{a}$ & $5.1 \pm 1.3 a^{\prime}$ & $2.9 \pm 1.1 \mathrm{~A}$ & $1.8 \pm 0.9 \mathrm{~A}^{\prime}$ & 21.93 \\
\hline FYY-299 & & $11.4 \pm 1.7 \mathrm{a}$ & $8.7 \pm 1.1 b^{\prime}$ & $2.3 \pm 0.1 \mathrm{AB}$ & $0.3 \pm 0.1 \mathrm{~B}^{\prime}$ & 22.80 \\
\hline XWX-17 & & $7.6 \pm 2.1 \mathrm{a}$ & $5.9 \pm 2.3 \mathrm{a}^{\prime}$ & $1.7 \pm 0.2 \mathrm{BC}$ & $0.3 \pm 007 \mathrm{~B}^{\prime}$ & 16.46 \\
\hline XWX-12 & & $9.2 \pm 0.9 \mathrm{a}$ & $4.7 \pm 1.5 \mathrm{a}$ & $1.3 \pm 0.3 \mathrm{C}$ & $0.3 \pm 0.04 \mathrm{~B}^{\prime}$ & 15.50 \\
\hline SY-9586 & husk & $4.77 \pm 0.64 \mathrm{a}$ & $3.29 \pm 0.45 \mathrm{a}^{\prime}$ & $1.33 \pm 0.23 \mathrm{~A}$ & $0.93 \pm 0.44 \mathrm{~A}^{\prime}$ & 10.31 \\
\hline
\end{tabular}




\begin{tabular}{|c|c|c|c|c|c|}
\hline FYY-299 & $2.88 \pm 0.86 \mathrm{~b}$ & $3.27 \pm 0.49 \mathrm{a}^{\prime}$ & $1.83 \pm 0.26 \mathrm{~B}$ & $0.42 \pm 0.04 \mathrm{~B}^{\prime}$ & 8.38 \\
\hline XWX-17 & $2.90 \pm 0.55 b$ & $1.31 \pm 0.25 \mathrm{~b}$ & $1.74 \pm 0.15 B$ & $0.32 \pm 0.03 \mathrm{~B}^{\prime}$ & 6.26 \\
\hline XWX-12 & $2.53 \pm 0.63 b$ & $3.17 \pm 2.53 \mathrm{a}^{\prime}$ & $1.64 \pm 0.11 \mathrm{~B}$ & $0.46 \pm 0.21 \mathrm{~B}^{\prime}$ & 7.79 \\
\hline SY-9586 & $5.73 \pm 0.73 a$ & ND & $1.75 \pm 0.42 \mathrm{~A}$ & ND & 7.47 \\
\hline FYY-299 & $4.44 \pm 0.23 b$ & ND & $1.70 \pm 0.02 \mathrm{~A}$ & ND & 6.14 \\
\hline XWX-17 & $3.39 \pm 1.12 \mathrm{c}$ & ND & $1.61 \pm 0.30 \mathrm{~A}$ & ND & 5.01 \\
\hline XWX-12 & $2.71 \pm 0.69 \mathrm{c}$ & ND & $2.32 \pm 0.39 \mathrm{~B}$ & ND & 5.03 \\
\hline
\end{tabular}

Note: a indicated that the total arsenic content added by the four arsenic speciation

808

contents

809 ND indicated that no relevant content was detected

810

811

812

813

814

815

816

817

818 Table 3 Correlation of Fe/As concentrations, total As concentrations in rice roots,

819 straw, husks, as well as grains, with physicochemical variables of soil solution

820 samples in the non-rhizosphere of rice $(n=12)$

\begin{tabular}{llllll}
\hline & \multicolumn{5}{c}{ rhizosphere } \\
& $\mathrm{pH}$ & $\mathrm{EC}$ & $\mathrm{Fe}$ & $\mathrm{As}$ & $\mathrm{As}(\mathrm{III})$ \\
\hline Fe in iron plaque & 0.391 & 0.491 & 0.539 & 0.231 & $0.708^{*}$ \\
As in iron plaque & 0.532 & 0.392 & 0.215 & 0.287 & $0.602^{*}$ \\
As in root & 0.053 & 0.310 & $0.588^{*}$ & 0.397 & 0.135 \\
As in straw & 0.230 & 0.246 & 0.020 & 0.277 & -0.010 \\
As in husk & 0.205 & -0.115 & 0.239 & 0.165 & 0.244 \\
As in grain & -0.363 & -0.242 & 0.215 & 0.224 & 0.439 \\
\hline
\end{tabular}



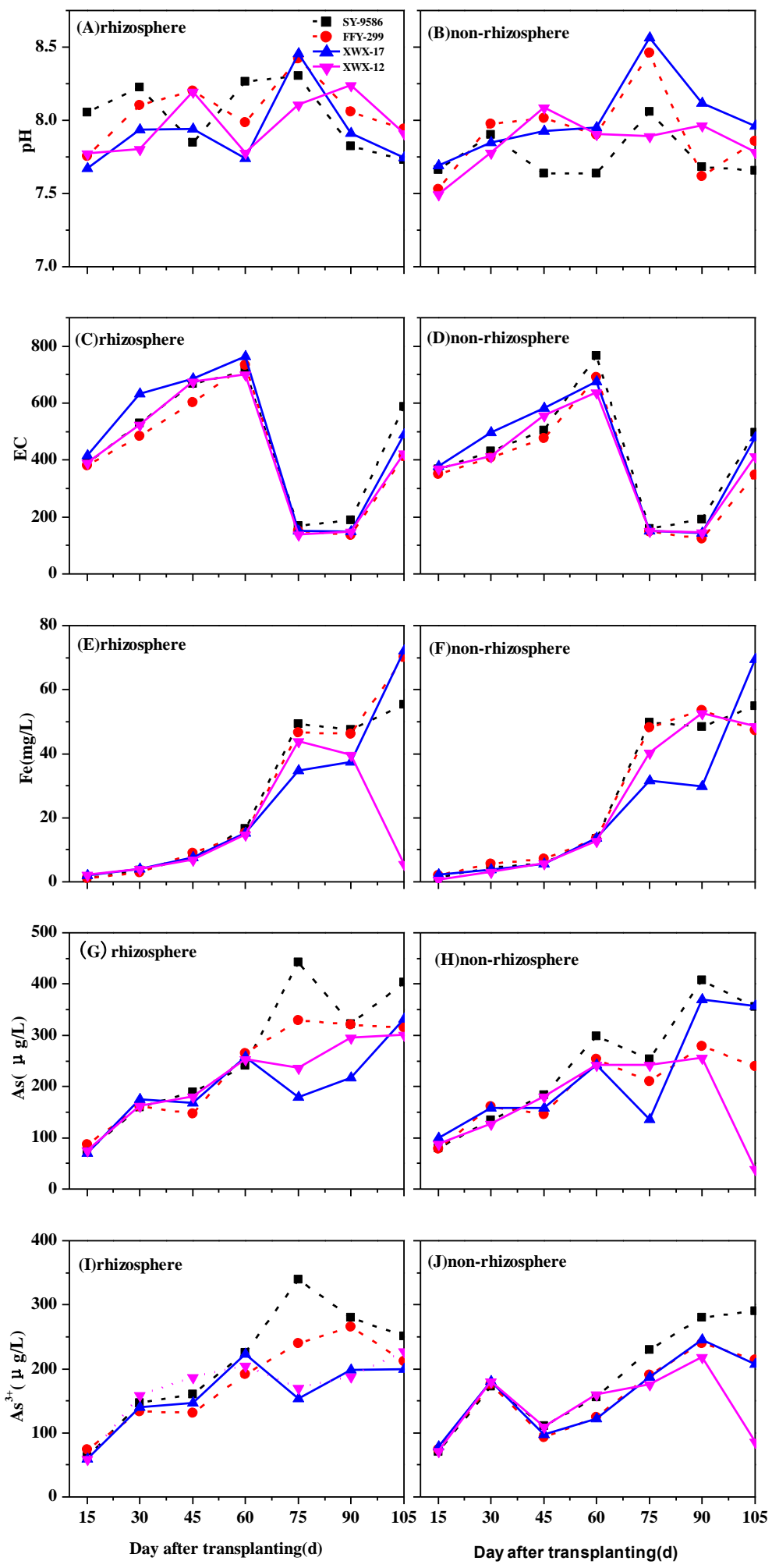
As(III) in soil solutions in rhizosphere and non- rhizospheres of four genotypes rice after $15 \mathrm{~d}, 30 \mathrm{~d}, 45 \mathrm{~d}, 60 \mathrm{~d}, 75 \mathrm{~d}, 90 \mathrm{~d}$, and $105 \mathrm{~d}$ growth 

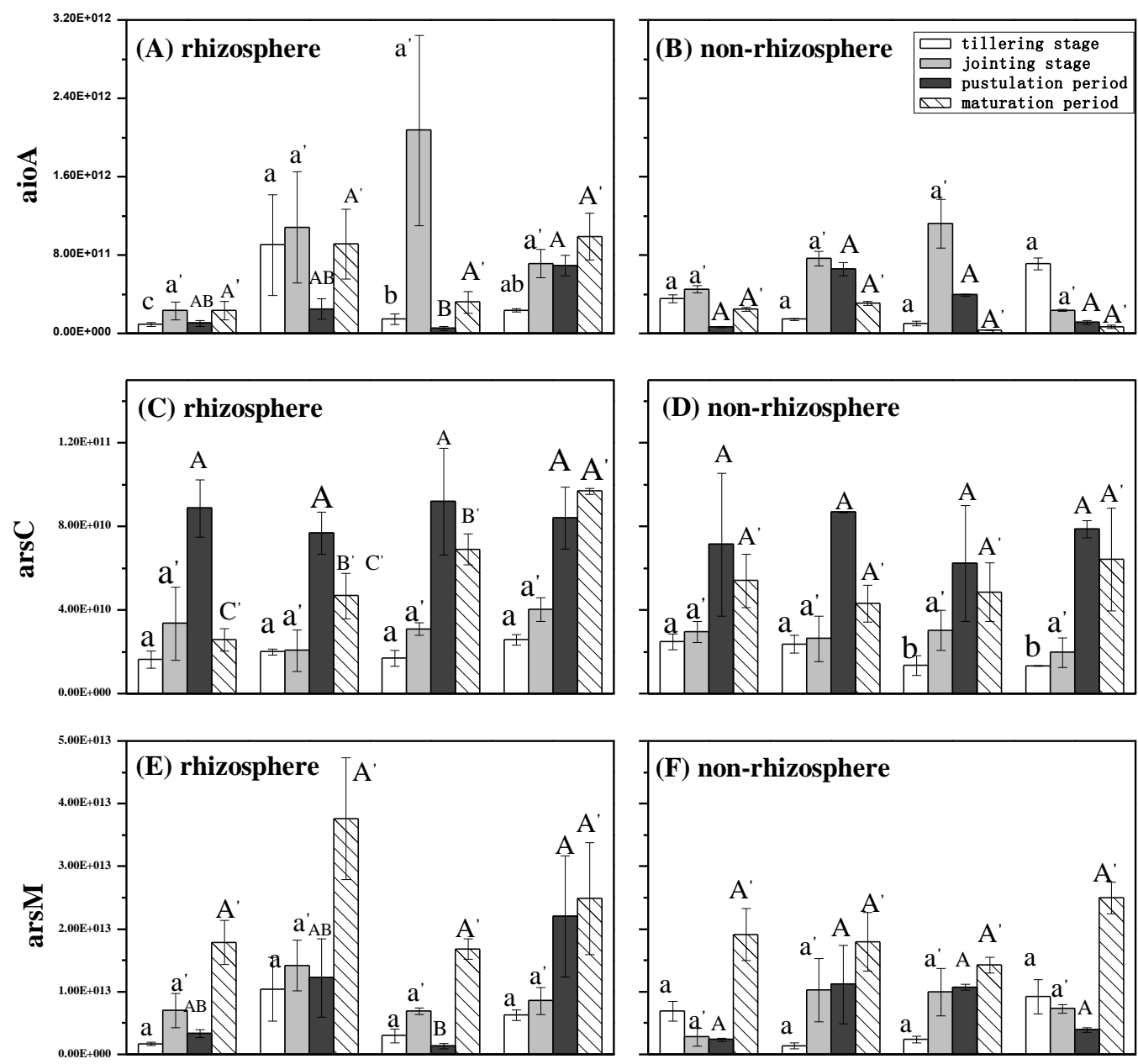

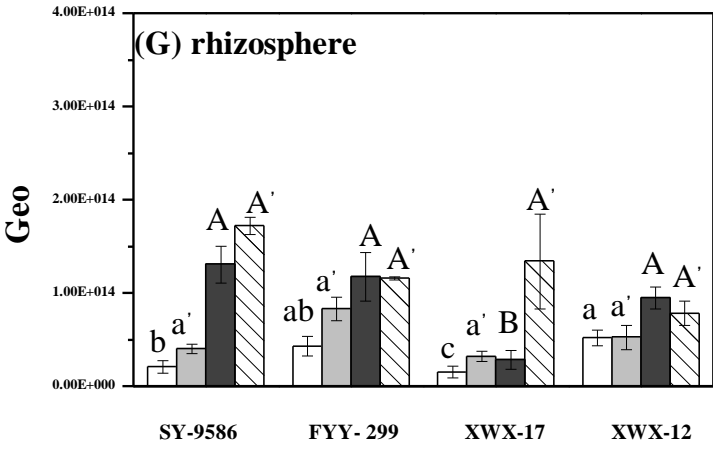

Rice varieties

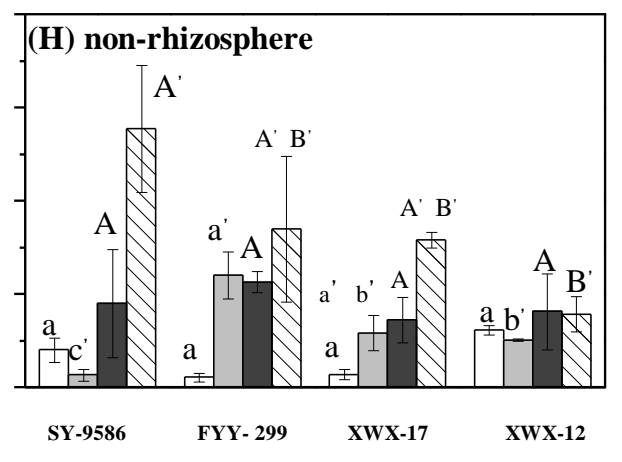

Rice varieties

Fig. 2. Copy numbers of aioA, arsC, arsM and Geo genes present in rhizosphere and nonrhizosphere soil samples in four growth stages of tillering, jointing, filling and maturation of rice with SY-9586、FYY-299、XWX-17 and XWX-12 genotypes 


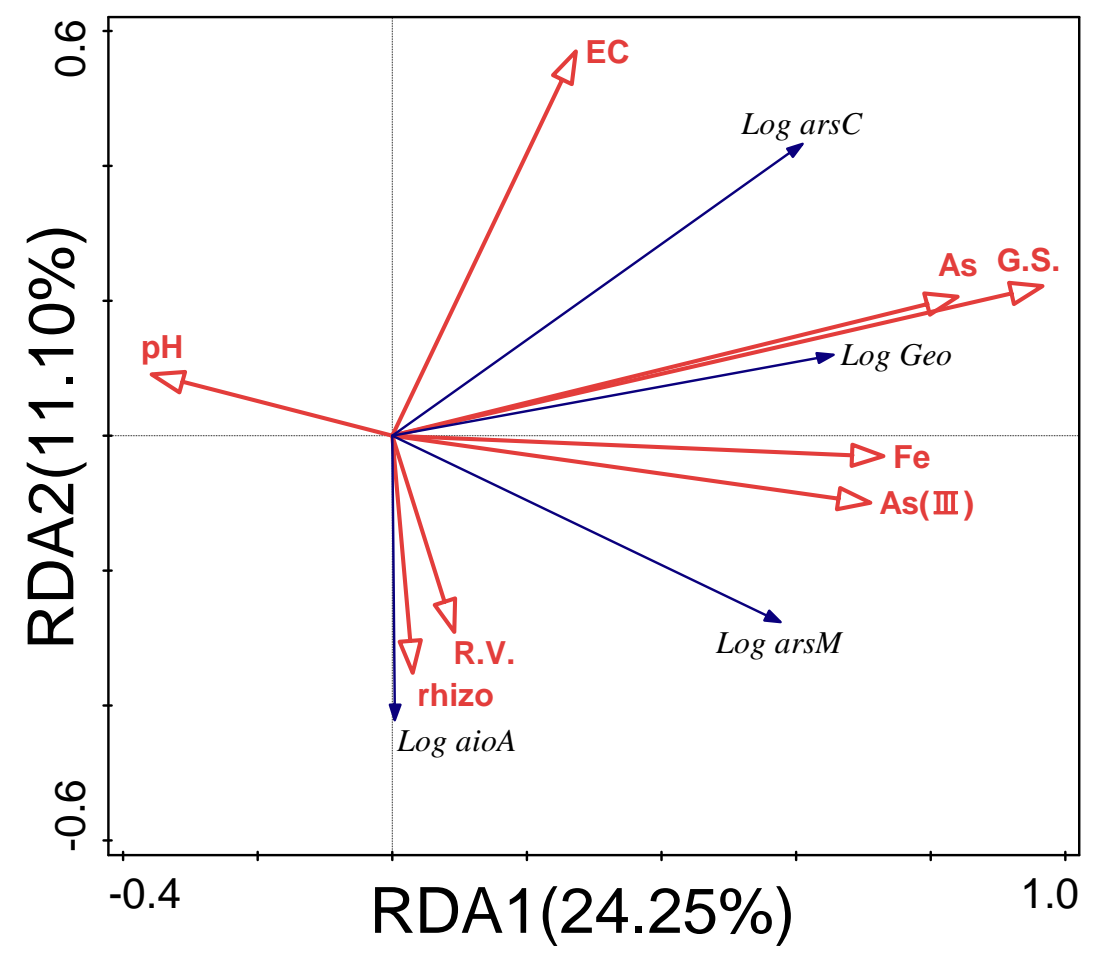

Fig. 3. RDA correlation of gene abundances of aioA, arsC, arsM and Geo with physicochemical variables of soil solution samples.

838 Note: G.S.: growth stage; As(III) means As(III) concentration in pore water; 839 R.V.: rice variety; Solid black arrows indicate the functional genes; Faint arrows $840 \quad$ indicate environmental factors. 

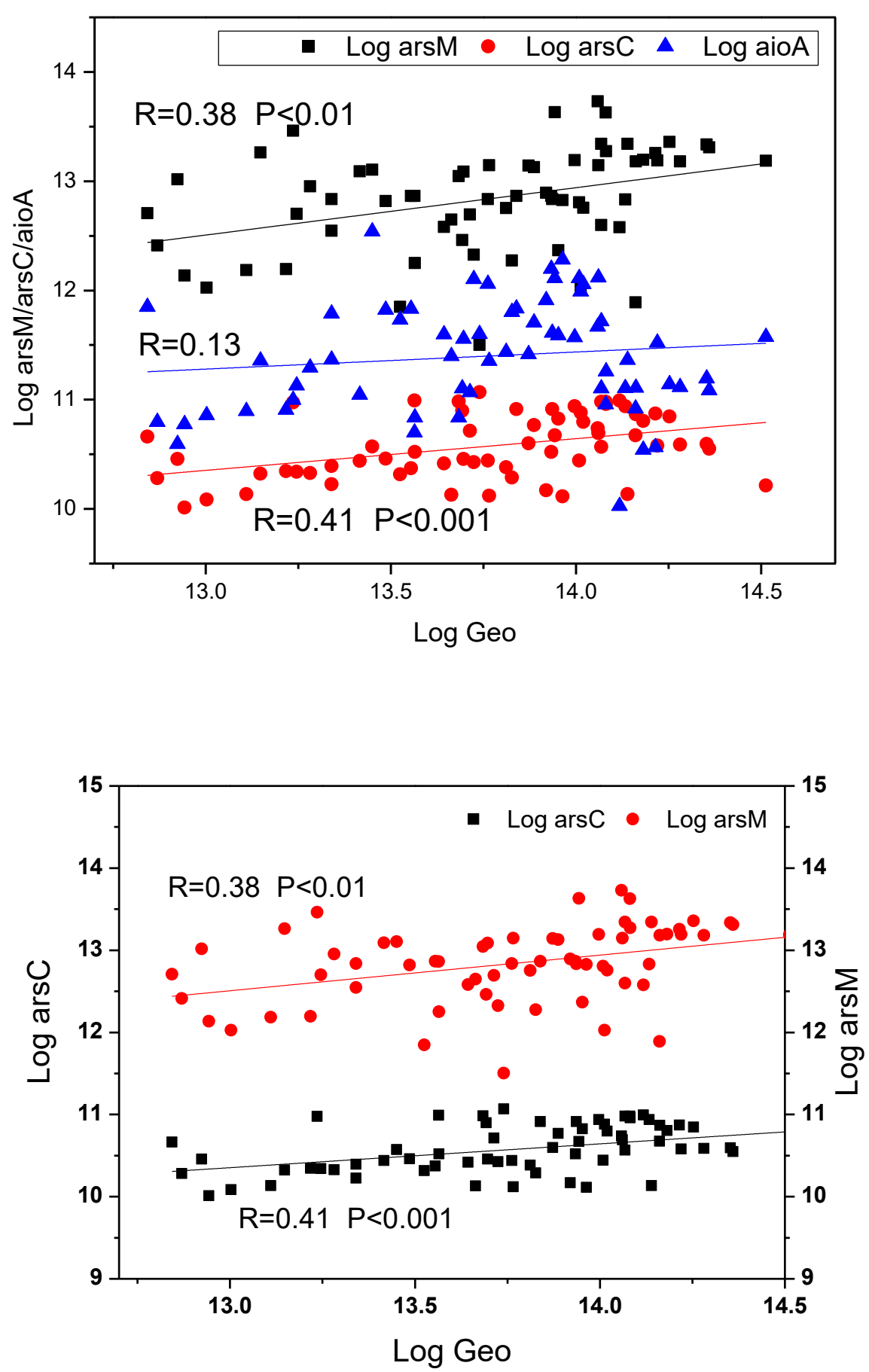

847

848 Fig. 4. Relationship among Geo gene abundance with arsC and arsM gene

849 abundance respectively 

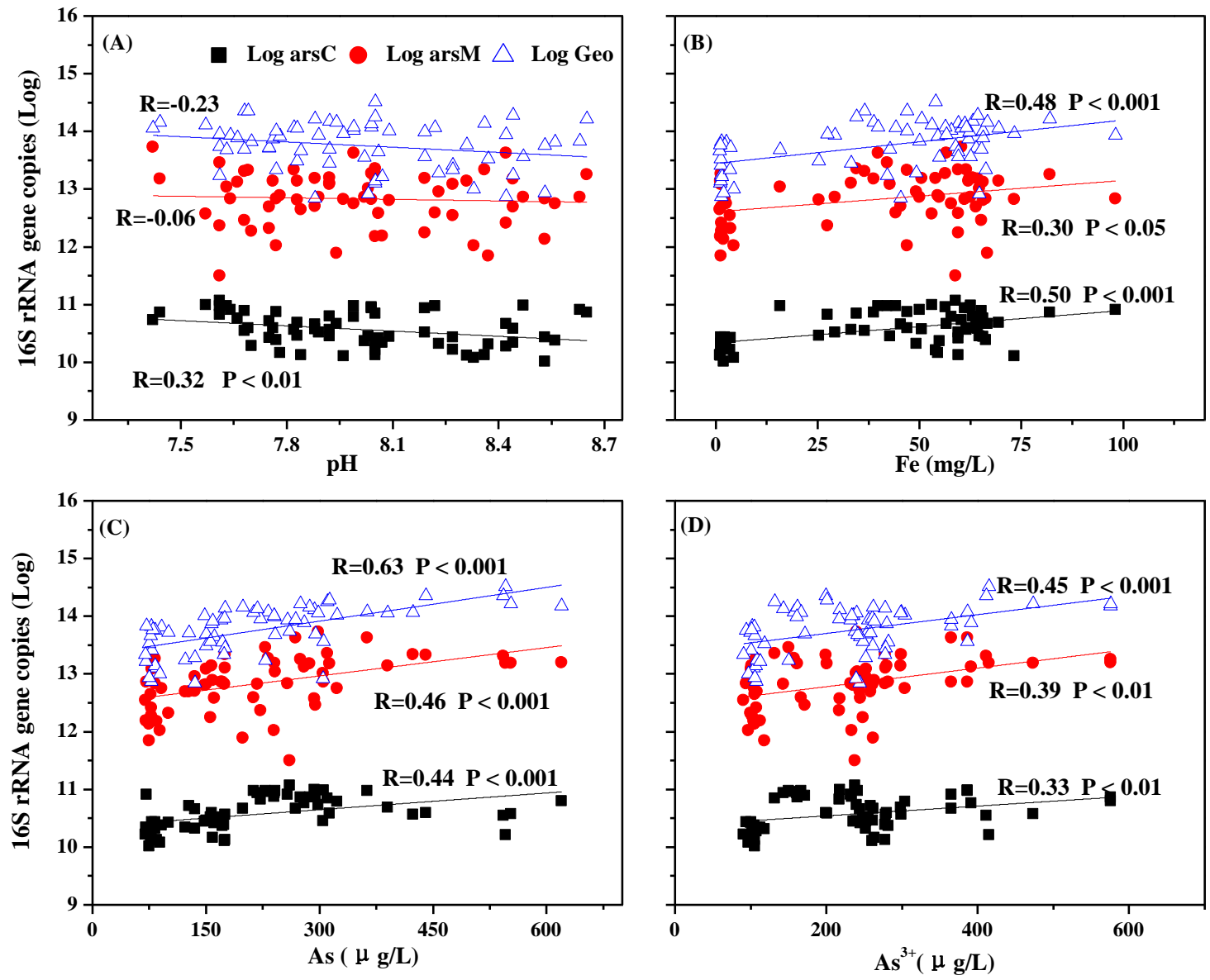

850

851

Fig. 5. Relationship among aioA, arsC, arsM and Geo gene abundance with $\mathrm{pH}$,

852 $\mathrm{Fe}$, As and As(III) concentration in soil solution respectively

853 

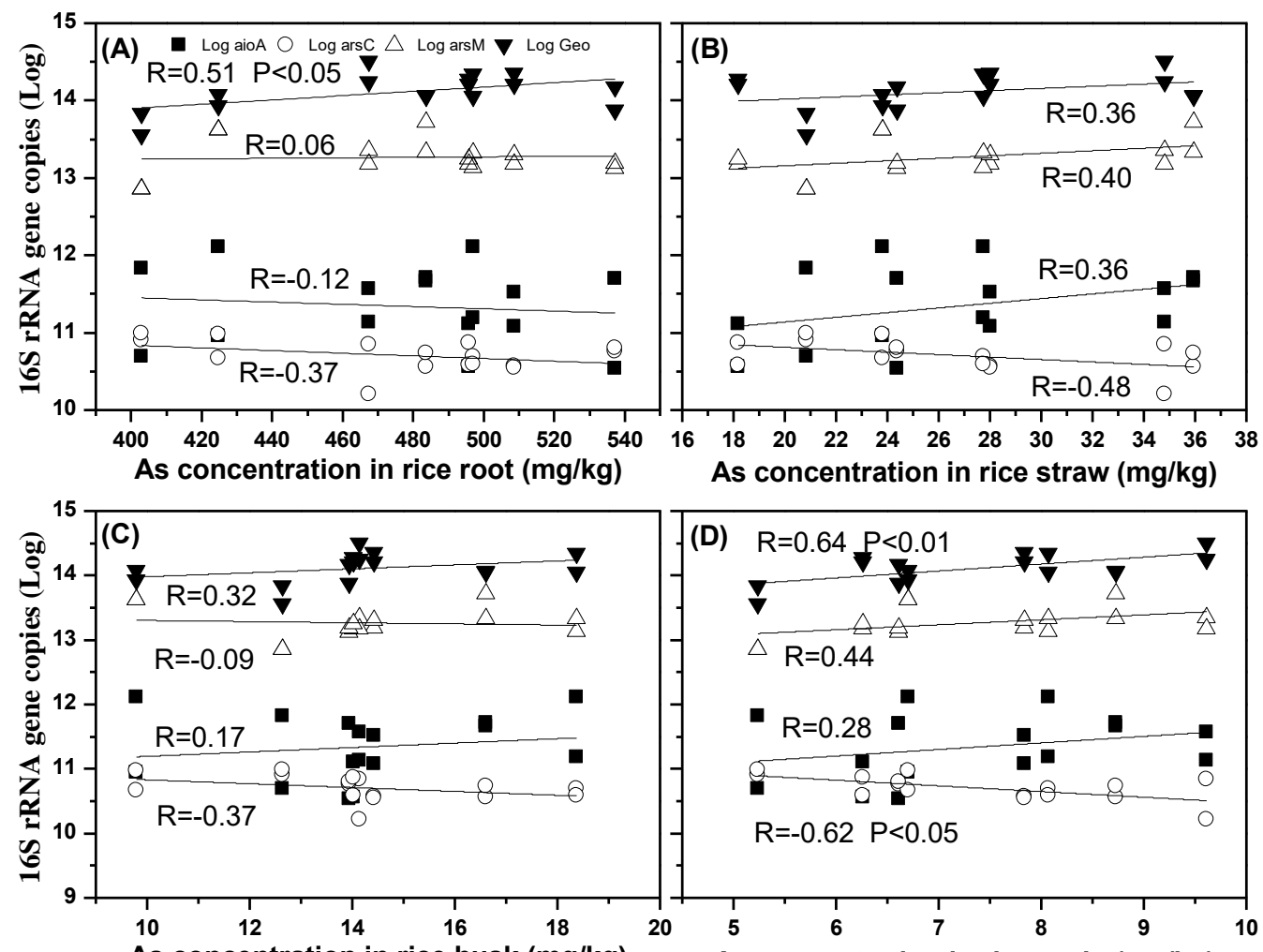

As concentration in rice husk $(\mathrm{mg} / \mathrm{kg})$

As concentration in rice grain $(\mathrm{mg} / \mathrm{kg})$
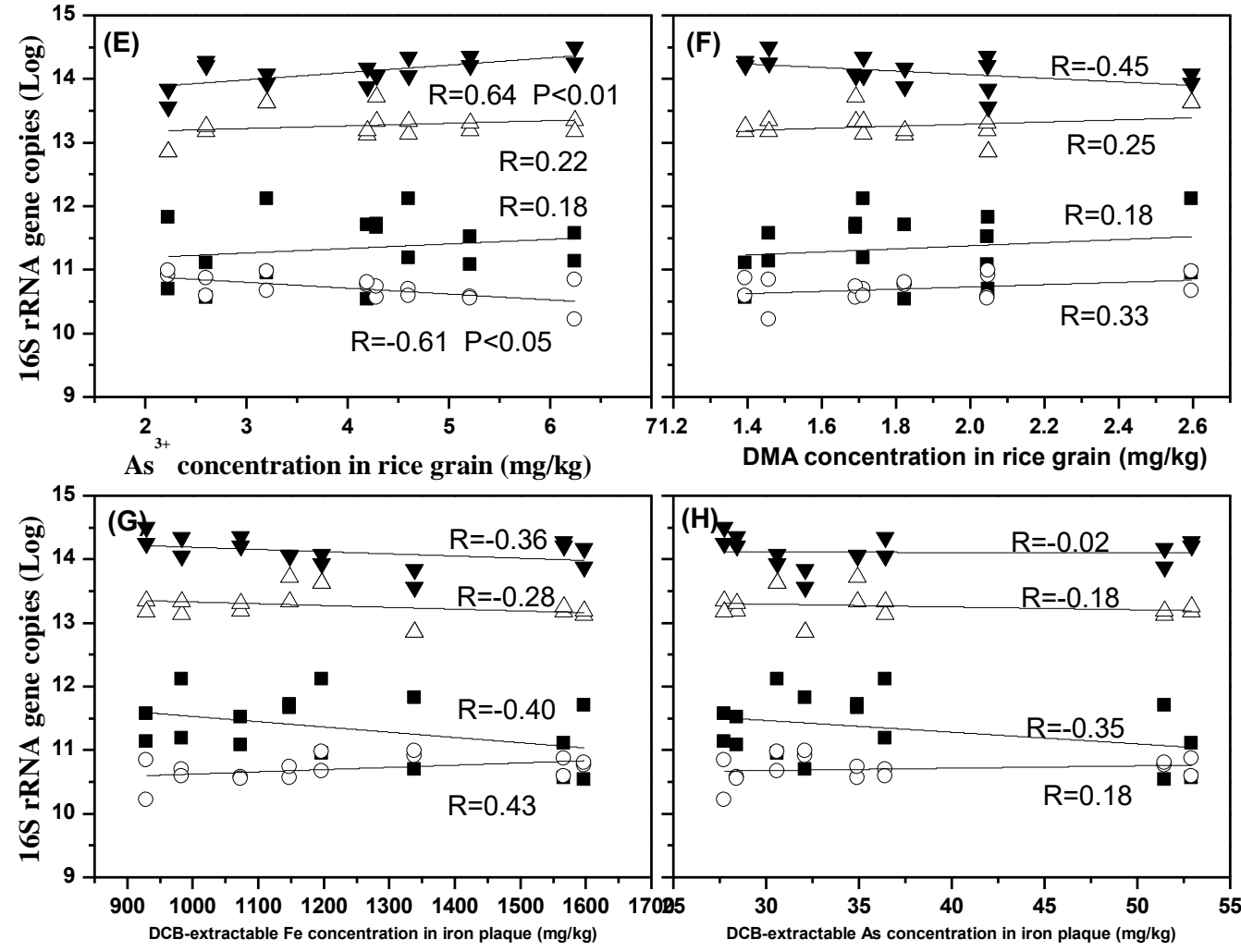

DMA concentration in rice grain $(\mathrm{mg} / \mathrm{kg})$

856 Fig. 6. Relationship among aioA, arsC, arsM and Geo gene abundance with As concentration in rice roots, straw, husk, grain, As(III)/DMA concentration in rice grain and DCB-extractable Fe/As concentration in iron plaque respectively. 

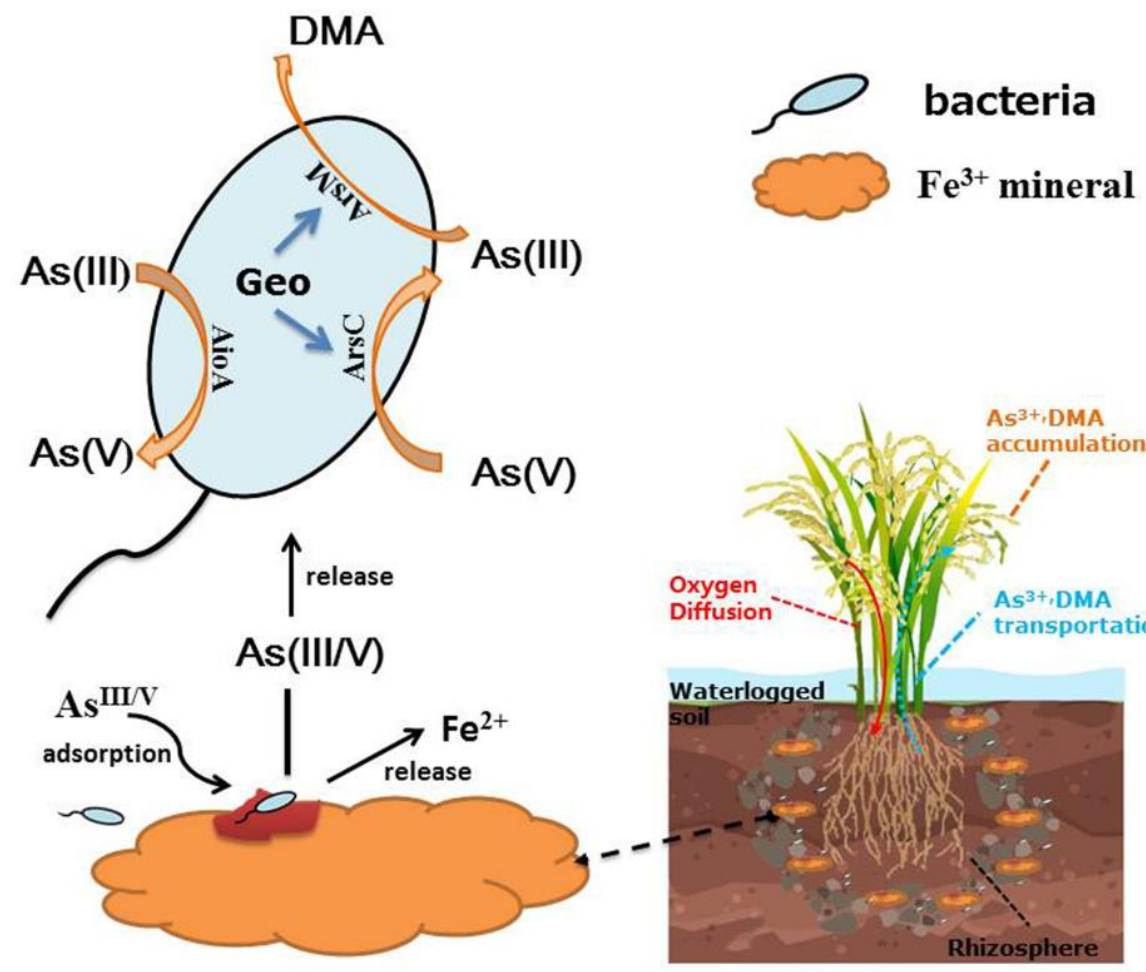

859

860 Fig. 7. The influencing mechanism of iron reduction on arsenic uptake in rice.

863

864

865

866

867

868

869

870

871 


\section{Supporting Information}

873 874 875

893 Table S1 basic properties of paddy soil used in this study AGGCYGGBCG) CTCTTTCGT) GCAGGGGTCAATA).

\section{Quantitative real-time PCR analysis of arsenic functional genes and iron} reduction genes. Soil samples were used to extract total microbial DNA using QuantiFast ${ }^{\circledR}$ SYBR ${ }^{\circledR}$ Green PCR Kit (Qiagen, Germany) according to the manufacturer's instructions. For the quantification of arsenic functional genes and iron reduction genes, each reaction was performed in a total volume of $16 \mu \mathrm{L}$,

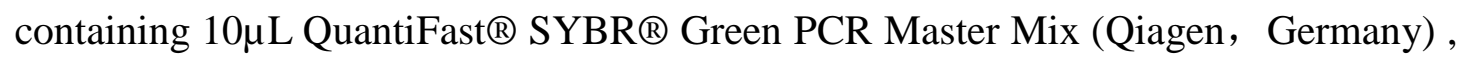
$0.8 \mu \mathrm{L}$ DNA template, $0.4 \mu \mathrm{L}$ of each $10 \mu \mathrm{M}$ primer, $0.2 \mu \mathrm{L} 10 \mu \mathrm{M}$ reverse primer, $1 \mu \mathrm{L}$ cDNA and $3.6 \mu \mathrm{L}$ nuclease-free water. The qPCR mixtures were firstly incubated at $95^{\circ} \mathrm{C}$, denatured for $5 \mathrm{~min}$, followed by 40 cycles at $95^{\circ} \mathrm{C}$ for $10 \mathrm{~s}$ and at $60^{\circ} \mathrm{C}$ for 30s. The sequence of primers were as follows: AroAdeg2F(GTCGGYTGYGGMTAYCAYGYYTA)/AroAdeg2(RYTCDGARTTGT amlt-42-f(TCACGCAATACCCTTGAAATGATC)/amlt-376-r(ACCTTTTCACCGTC arsMF1(TCYCTCGGCTGCGGCAAYCCVAC)/arsMR2(CGWCCGCCWGGCTTW AGYACCCG) and Geo564F(AAGCGTTGTTCGGAWTTAT)/Geo840R(GGCACT 


\begin{tabular}{|c|c|c|c|c|c|c|c|c|c|}
\hline & $\mathrm{pH}$ & $\begin{array}{l}\mathrm{EC} \\
(\mathrm{ms} / \mathrm{cm})\end{array}$ & $\begin{array}{l}\mathrm{OM}^{\mathrm{a}} \\
(\mathrm{g} / \mathrm{kg})\end{array}$ & $\begin{array}{l}\text { Avail } \mathrm{K}^{\mathrm{b}} \\
(\mathrm{mg} / \mathrm{kg})\end{array}$ & $\begin{array}{l}\text { Avail Nc } \\
(\mathrm{g} / \mathrm{kg})\end{array}$ & $\begin{array}{l}\mathrm{Fe} \\
(\mathrm{g} / \mathrm{kg})\end{array}$ & $\begin{array}{l}\mathrm{Al} \\
(\mathrm{g} / \mathrm{kg})\end{array}$ & $\begin{array}{l}\mathrm{Mn} \\
(\mathrm{g} / \mathrm{kg})\end{array}$ & $\begin{array}{l}\text { As } \\
(\mathrm{mg} / \mathrm{kg})\end{array}$ \\
\hline soil & 7.54 & 1.61 & 4.1 & 42.62 & 0.69 & 40.03 & 65.16 & 2.10 & 130.2 \\
\hline
\end{tabular}

894

895 Table S2 Correlation matrix of physicochemical variables of soil solution samples in

896 non-rhizosphere soil $(\mathrm{n}=84)$

\begin{tabular}{llllll}
\hline & $\mathrm{pH}$ & $\mathrm{EC}$ & $\mathrm{Fe}$ & $\mathrm{As}$ & $\mathrm{As}(\mathrm{III})$ \\
\hline $\mathrm{pH}$ & & & & & \\
$\mathrm{EC}$ & $-0.271^{*}$ & & & & \\
$\mathrm{Fe}$ & $-0.351^{* *}$ & $-0.445^{* *}$ & & & \\
$\mathrm{As}$ & -0.081 & -0.023 & $0.232^{*}$ & & \\
$\mathrm{As}(\mathrm{III})$ & $-0.582^{* *}$ & $0.417^{* *}$ & $0.836^{* *}$ & $0.244^{*}$ & \\
\hline
\end{tabular}

$897 *$ indicated that there is a significant difference $(* \mathrm{P}<0.05)$

$898 * *$ indicated that there is a fearfully significant difference $(* * \mathrm{P}<0.01)$

899

900 Table S3 Biomass (g/plant, wet weight) of rice roots, straws and grain of four

901 genotypes

\begin{tabular}{|c|c|c|c|}
\hline Rice varieties & root & straw & grain \\
\hline SY-9586 & $41.9 \pm 10.3$ & $62.9 \pm 9.6$ & $12.7 \pm 4.4$ \\
\hline FYY-299 & $65.1 \pm 10.4$ & $119.8 \pm 48.4$ & $15.5 \pm 6.7$ \\
\hline XWX-17 & $43.1 \pm 10.2$ & $61.5 \pm 8.6$ & $8.2 \pm 1.9$ \\
\hline XWX-12 & $63.8 \pm 7.2$ & $81.9 \pm 5.6$ & $10.1 \pm 1.8$ \\
\hline $\begin{array}{l}\text { Analysis of variance } \\
\text { Genotype }(G)\end{array}$ & NS & $* \mathrm{P}<0.05$ & $* \mathrm{P}<0.05$ \\
\hline
\end{tabular}

902 NS indicates that there is no significant difference

903

904 Table S4 Fe and As concentration on Fe plaque of rice roots with different genotypes

\begin{tabular}{lll}
\hline varieties & $\mathrm{Fe}(\mathrm{mg} / \mathrm{kg})$ & $\mathrm{As}(\mathrm{mg} / \mathrm{kg})$ \\
\hline SY-9586 & $1059 \pm 91.8 \mathrm{~b}$ & $35.2 \pm 8.47 \mathrm{a}$ \\
FYY-299 & $925 \pm 255.8 \mathrm{~b}$ & $34.1 \pm 10.1 \mathrm{a}$ \\
XWX-17 & $1486 \pm 298.4 \mathrm{a}$ & $44.5 \pm 10.9 \mathrm{a}$ \\
\hline
\end{tabular}




\begin{tabular}{lll}
\hline XWX-12 & $1156 \pm 160.2 \mathrm{~b}$ & $37.3 \pm 11.7 \mathrm{a}$ \\
Analysis of variance Genotype $(\mathrm{G})$ & $* \mathrm{P}<0.05$ & $\mathrm{NS}$ \\
\hline
\end{tabular}

905

906 Table S5 Total As concentrations of rice roots, straws and grain of the four genotypes

$907 \quad(\mathrm{mg} / \mathrm{kg})($ mean $\pm \mathrm{SD}, \mathrm{n}=4)$

\begin{tabular}{lllll}
\hline Rice varieties & root & straw & husk & grain \\
\hline SY-9586 & $478 \pm 26.2$ & $31.4 \pm 4.81$ & $14.8 \pm 0.84$ & $8.05 \pm 1.41$ \\
FYY-299 & $475 \pm 27.9$ & $28.3 \pm 7.22$ & $17.5 \pm 1.26$ & $8.62 \pm 0.78$ \\
XWX-17 & $528 \pm 31.2$ & $22.3 \pm 2.61$ & $13.9 \pm 0.06$ & $6.26 \pm 1.22$ \\
XWX-12 & $413 \pm 16.5$ & $24.5 \pm 5.77$ & $7.78 \pm 0.29$ & $5.90 \pm 1.12$ \\
Analysis of variance & $* \mathrm{P}<0.05$ & NS & NS & NS \\
Genotype (G) & & & &
\end{tabular}

908

909

校对报告

910

911 当前使用的样式是 [Soil Biology Biochemistry]

912 当前文档包含的题录共77条

913 有0条题录存在必填字段内容缺失的问题

914 所有题录的数据正常 